US Army Corps

of Engineers

Waterways Experiment

Station

Monitoring Completed Navigation Projects Program

\title{
Inspections of Previously Monitored Coastal Structures
}

by Robert R. Bottin, Jr., Larry R. Tolliver

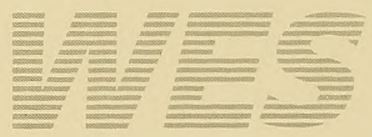

Approved For Public Release; Distribution Is Unlimited

TA
7
. W34
no.
CHL-
$99-3$

Prepared for Headquarters, U.S. Army Corps of Engineers 
The contents of this report are not to be used for advertising, publication, or promotional purposes. Citation of trade names does not constitute an official endorsement or approval of the use of such commercial products.

The findings of this report are not to be construed as an official Department of the Army position, unless so designated by other authorized documents. 


\section{Inspections of Previously Monitored Coastal Structures}

by Robert R. Bottin, Jr., Larry R. Tolliver

U.S. Army Corps of Engineers

Waterways Experiment Station

3909 Halls Ferry Road

Vicksburg, MS 39180-6199

Final report

Approved for public release; distribution is unlimited

Prepared for U.S. Army Corps of Engineers

Washington, DC 20314-1000 


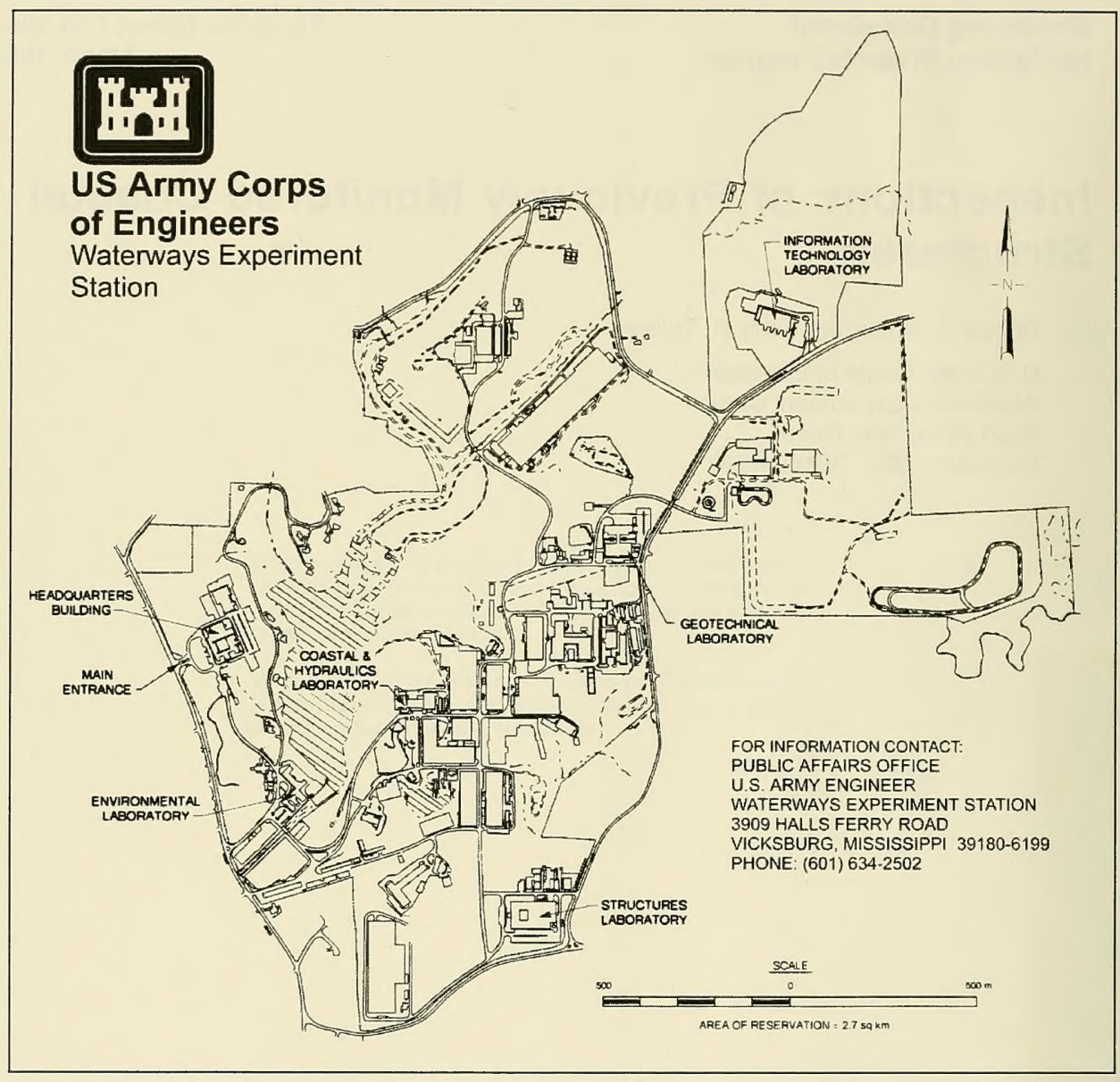

\section{Waterways Experiment Station Cataloging-in-Publication Data}

Bottin, Robert R.

Inspections of previously monitored coastal structures / by Robert R. Bottin, Jr., Larry R.

Tolliver ; prepared for U.S. Army Corps of Engineers.

60 p. : ill. ; 28 cm. - (Technical report ; CHL-99-3)

Includes bibliographic references.

1. Hydraulic structures - Inspection. 2. Coastal engineering. 3. Armourstone -Inspection. 4. Breakwaters - Inspection. 5. Jetties - Inspection. I. Tolliver, Larry R. II. United States. Army. Corps of Engineers. III. U.S. Army Engineer Waterways Experiment Station. IV. Coastal and Hydraulics Laboratory (U.S. Army Engineer Waterways Experiment Station) V. Monitoring Completed Navigation Projects Program (U.S.) VI. Title. VIII. Series: Technical report (U.S. Army Engineer Waterways Experiment Station) ; CHL-99-3.

TA7 W34 no.CHL-99-3 


\section{Contents}

Preface ................. iv

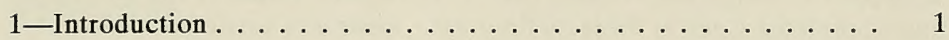

Monitoring Completed Navigation Projects Program . . . . . . 1

Objective of Periodic Inspections Work Unit . . . . . . . . 2

Study Scope ..................... 3

2-Project Descriptions and Inspection Results $\ldots \ldots \ldots \ldots \ldots$

Nawiliwili Harbor Breakwater, Hawaii . . . . . . . . . . 6

Kahului Harbor Breakwaters, Hawaii . . . . . . . . . . . . 8

Laupahoehoe Boat-Launching Facility Breakwater, Hawaii . . . . 12

Yaquina Bay North Jetty, Oregon . . . . . . . . . . . . . . . 14

Siuslaw River Jetties, Oregon . . . . . . . . . . . . . . . . 17

Umpqua River Training Jetty, Oregon . . . . . . . . . . . . 21

Crescent City Harbor Breakwater, California . . . . . . . . . 24

Spud Point Marina Breakwater, California . . . . . . . . . 25

Fisherman's Wharf Harbor Breakwater, California . . . . . . . 29

Burns Harbor Breakwater, Indiana . . . . . . . . . . . 30

Cleveland Harbor East Breakwater, Ohio . . . . . . . . . . . 36

Cattaraugus Creek Harbor Breakwater, New York . . . . . . . 39

Manasquan Inlet Jetties, New Jersey . . . . . . . . . . . 42

Ocean City Inlet South Jetty, Maryland . . . . . . . . . . . . 45

3-Summary and Recommendations $\ldots \ldots \ldots \ldots \ldots \ldots$

References $\ldots \ldots \ldots \ldots \ldots \ldots \ldots \ldots \ldots$

SF 298 


\section{Preface}

The study reported herein was conducted as part of the Monitoring Completed Navigation Projects (MCNP) Program, formerly the Monitoring Completed Coastal Projects Program. Work was carried out under Work Unit 11M-7, "Periodic Inspections." Overall program management for MCNP is accomplished by the Hydraulic Design Section of Headquarters, U.S. Army Corps of Engineers (HQUSACE). The Coastal and Hydraulics Laboratory (CHL), U.S. Army Engineer Waterways Experiment Station (WES), is responsible for technical and data management support for HQUSACE review and technology transfer. Technical Monitors for the MCNP program are Messrs. John P. Bianco, Barry W. Holliday, and Charles B. Chesnutt, HQUSACE. The Program Manager is Mr. E. Clark McNair, Jr., CHL.

This report presents results of inspections of coastal structures that have been previously monitored under the MCNP program. The information contained in this report was gathered as a result of walking inspections of the structures by Mr. Robert R. Bottin, Jr., and/or Messrs. Larry R. Tolliver, Dennis G. Markle, and Hugh F. Acuff, all of the Harbors and Entrances Branch, Navigation and Harbors Division, CHL.

The work was conducted during the period June 1997 through September 1998 under the general supervision of Dr. James R. Houston, Director, and Mr. Charles C. Calhoun, Jr., Assistant Director, CHL, and under the direct supervision of Messrs. C. E. Chatham, Jr., Chief, Navigation and Harbors Division, CHL, and Dennis G. Markle, Chief, Harbors and Entrances Branch, Navigation and Harbors Division. This report was prepared by Messrs. Bottin, Research Physical Scientist, and Tolliver, Civil Engineering Technician.

During the publication of this report, Commander of WES was COL Robin R. Cababa, EN. 


\section{Introduction}

\section{Monitoring Completed Navigation Projects Program}

The goal of the Monitoring Completed Navigation Projects (MCNP) Program (formerly the Monitoring Completed Coastal Projects Program) is the advancement of coastal and hydraulic engineering technology. The program is designed to determine how well projects are accomplishing their purposes and are resisting attacks by the physical environment. These determinations, combined with concepts and understanding already available, will lead to predicting more credible engineering solutions to coastal and hydraulic problems; to strengthening and improving design criteria and methodology; to improving construction practices and costeffectiveness; and to improving operation and maintenance techniques. Additionally, the monitoring program will identify where current technology is inadequate or where additional research is required.

To develop the direction for the program, the U.S. Army Corps of Engineers established an ad hoc committee of engineers and scientists. The committee formulated the objectives of the program, developed its operational philosophy, recommended funding levels, and established criteria and procedures for project selection. A significant result of their efforts was a prioritized listing of problem areas to be addressed, essentially a listing of the areas of interests of the program.

Corps offices are invited to nominate projects for inclusion in the monitoring program as funds become available. A selection committee, composed of members of the MCNP Program Field Review Group (representatives from District and Division offices) and civilian members of the Coastal Engineering Research Board, reviews and prioritizes the projects nominated. The prioritized list is reviewed by the Program Monitors at Headquarters, U.S. Army Corps of Engineers (HQUSACE). Final selection is based on this prioritized list, national priorities, and the availability of funding.

The overall monitoring program is under the management of the Coastal and Hydraulics Laboratory (CHL), U.S. Army Engineer Waterways Experiment Station (WES), with guidance from HQUSACE. An 
individual monitoring project is a cooperative effort between the submitting District/Division office and CHL. Development of monitoring plans and the conduct of data collection and analyses are dependent upon the combined resources of CHL and the District/Division.

Inspections of the coastal structures for the study reported herein were completed as part of the "Periodic Inspections" work unit of the MCNP program.

\section{Objective of Periodic Inspections Work Unit}

The objective of the "Periodic Inspections" work unit in the MCNP program is to monitor selected coastal navigation structures periodically to gain an understanding of the long-term structural response of unique structures to their environment. These periodic data sets are used to improve knowledge in design, construction, and maintenance of both existing and proposed coastal navigation projects. These data also will help avoid repeating past design mistakes that have resulted in structure failure and/or high maintenance costs. Past projects monitored under the MCNP program and/or structures with unique design features that may have application at other sites are considered for inclusion in the periodic inspections monitoring program. Selected sites are presented as candidates for development of a periodic monitoring plan. Those sites receiving favorable response during MCNP program review are inspected and a monitoring plan is developed and presented for approval. Once the monitoring plan for a site is approved by the field review group and funds are provided, monitoring of the site is initiated. Normally, base conditions are established and documented in the initial effort. The site then is reinspected periodically (frequency of surveys is based on a balance of need and funding for each monitoring site) to obtain long-term structural performance data.

Relatively low cost remote sensing methods and techniques, with limited ground truthing surveys, are the primary inspection tools used in the monitoring efforts. Most periodic inspections consist of capturing above-water conditions of the structure at periodic intervals using highresolution aerial photography. Periodic aerial photographs are compared visually to gauge the degree of in-depth analysis required to quantify structural changes (primarily armor unit movement). Data analysis involves using photogrammetric techniques developed for and successfully applied at other coastal sites. At sites where local wave data are being gathered by other projects and/or agencies, and these data can be acquired at a relatively low cost, wave data are correlated with structural changes. In areas where these data are not available, general observations and/or documentation of major storms occurring in the locality are presented along with the monitoring data. Ground surveys are limited to the level needed to establish the accuracy of the photogrammetric techniques. 
When a coastal structure is photographed at low tide, an accurate permanent record of all visible armor units is obtained. Through the use of stereoscopic, photogrammetric instruments in conjunction with photographs, details of structure geometry can be defined at a point in time. By direct comparison of photographs taken at different times, as well as the photogrammetric data resolved from each set of photographs, geometric changes (i.e., armor unit movement and/or breakage) of the structure can be defined as a function of time. Thus, periodic inspections of the structures will capture permanent data that can be compared and analyzed to determine if structure changes are occurring that indicate possible failure modes and the need to monitor the structure(s) more closely.

\section{Study Scope}

It was requested in the 1996 Program Review that structures monitored during past MCNP efforts be revisited to determine how they are performing in their environments. These were to be expedient, low-cost inspections, and would be performed under the "Periodic Inspections" work unit of the MCNP program.

The coastal structures visited during the conduct of this study included those monitored under the MCNP program since its inception through 1995. Fourteen coastal structures were visited with their approximate locations shown in Figure 1. Numbers in the figure correspond to the sites shown in the following tabulation.

\begin{tabular}{||l|l|}
\hline Number & Coastal Site \\
\hline \hline 1 & Nawiliwili Harbor breakwater, Hawaii \\
\hline 2 & Kahului Harbor breakwaters, Hawaii \\
\hline 3 & Laupahoehoe Boat-Launching Facility breakwater, Hawaii \\
\hline 4 & Yaquina Bay north jetty, Oregon \\
\hline 5 & Siuslaw River jetties, Oregon \\
\hline 6 & Umpqua River training jetty, Oregon \\
\hline 7 & Crescent City Harbor breakwater, California \\
\hline 8 & Spud Point Marina breakwater, California \\
\hline 9 & Fisherman's Wharf Harbor breakwater, California \\
\hline 10 & Burns Harbor breakwater, Indiana \\
\hline 11 & Cleveland Harbor east breakwater, Ohio \\
\hline 12 & Cattaraugus Creek Harbor breakwater, New York \\
\hline 13 & Manasquan Inlet jetties, New Jersey \\
\hline 14 & Ocean City Inlet south jetty, Maryland \\
\hline
\end{tabular}




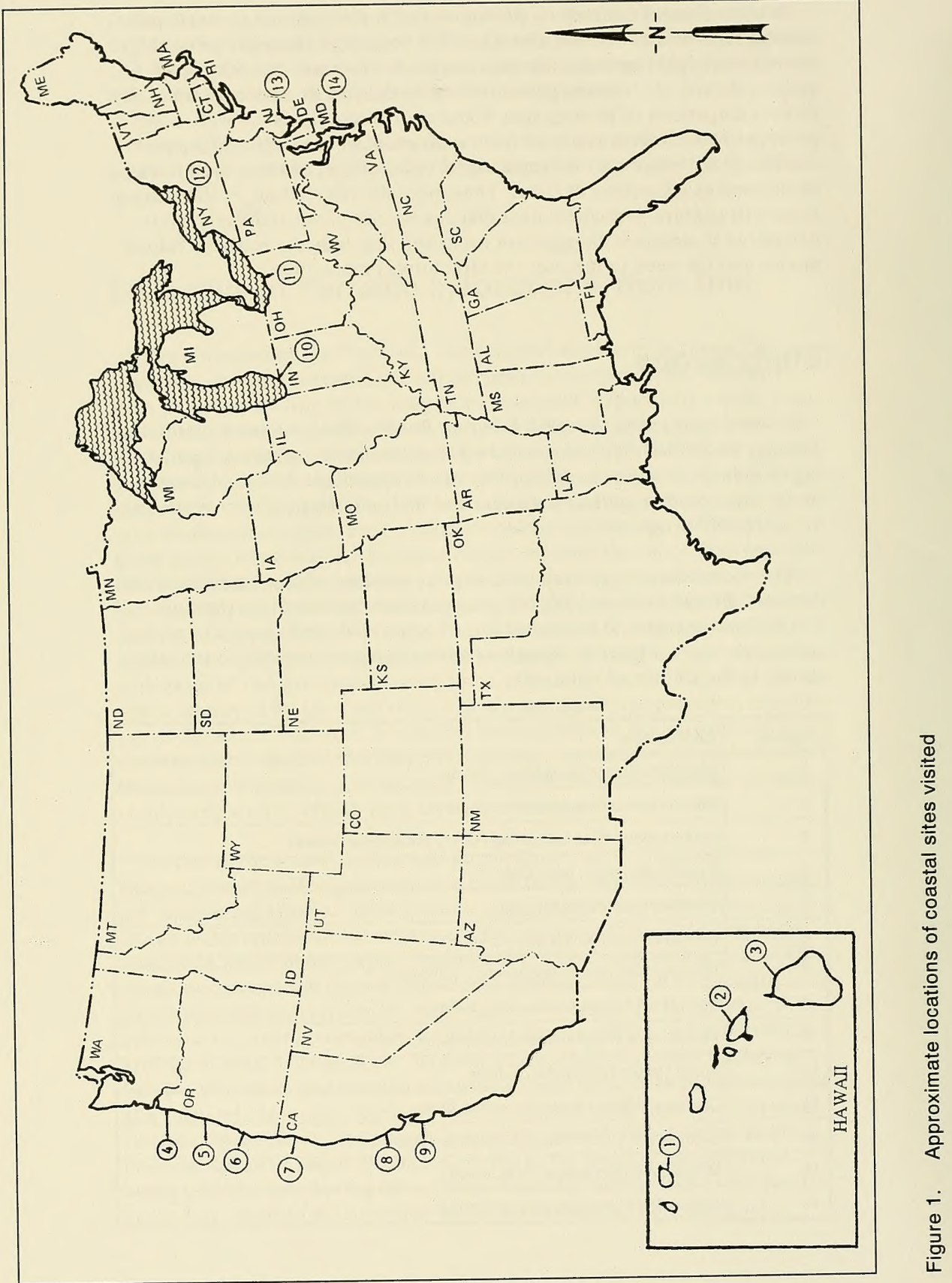


Inspections and assessments of the coastal structures at the various sites did not include the use of instrumentation. Rather, walking inspections and/or boat surveys were conducted, and armor unit positions during the inspections versus their positions in previous aerial photography generally were compared. Settlement of portions of the structures as well as voids in their armor also were noted, and photographs of the structures were obtained. In some instances, District personnel accompanied CHL personnel during the assessments. These procedures were considered adequate to obtain expedient, low-cost information required about the performance of the structures. 


\section{Project Descriptions and Inspection Results}

\section{Nawiliwili Harbor Breakwater, Hawaii}

Nawiliwili Harbor is located on the southeast coast of the island of Kauai approximately $185 \mathrm{~km}$ (115 miles $)^{1}$ northwest of Honolulu, Oahu, Hawaii. The harbor is protected by a $625-\mathrm{m}$-long $(2,050-\mathrm{ft}-\mathrm{long})$ rubblemound breakwater (Figure 2). The structure was originally constructed with a single layer of keyed and fitted, 9,070-kg (10-ton) armor stone. The structure has had a long history of repair since its original construction was completed in 1922. It has repeatedly been subjected to major storm events, including three hurricanes, during its history.

The first major rehabilitation of the structure in 1959 used $16,150-\mathrm{kg}$ (17.8-ton) tribar armor units. Two-layer, random placement was used on

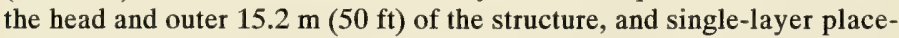
ment was used along $152 \mathrm{~m}(500 \mathrm{ft})$ of trunk on the seaside slope. Another rehabilitation initiated in 1977 consisted of 9,980-kg (11-ton) dolos armor units. Two layers of dolosse were placed from the toe to an elevation (el) of approximately $+1.5 \mathrm{~m}(+5.0 \mathrm{ft})$ mean lower low water $(\mathrm{mllw})$ over the one-layer tribar trunk section. In addition, two layers of dolosse were placed from the toe to the crest on the sea-side slope of the trunk for a distance of $91 \mathrm{~m}(300 \mathrm{ft})$ shoreward of the tribar area. The structure was again rehabilitated in 1987 with $20,865-\mathrm{kg}$ (23-ton) dolosse. These units were placed along the steepened head section below the water surface and randomly in low areas around the existing head above the water line. On the harbor-side slope, one layer of $5,900-\mathrm{kg}$ (6.5-ton) tribars was placed along a portion of deteriorated trunk. In addition, a $260-\mathrm{m}-\mathrm{long}$ (850-ft-long) concrete rib cap was constructed to buttress the concrete armor units and stabilize the breakwater crown.

1 Units of measurement in the text of this report are shown in SI (metric) units, followed by non-SI (British) units in parentheses. 


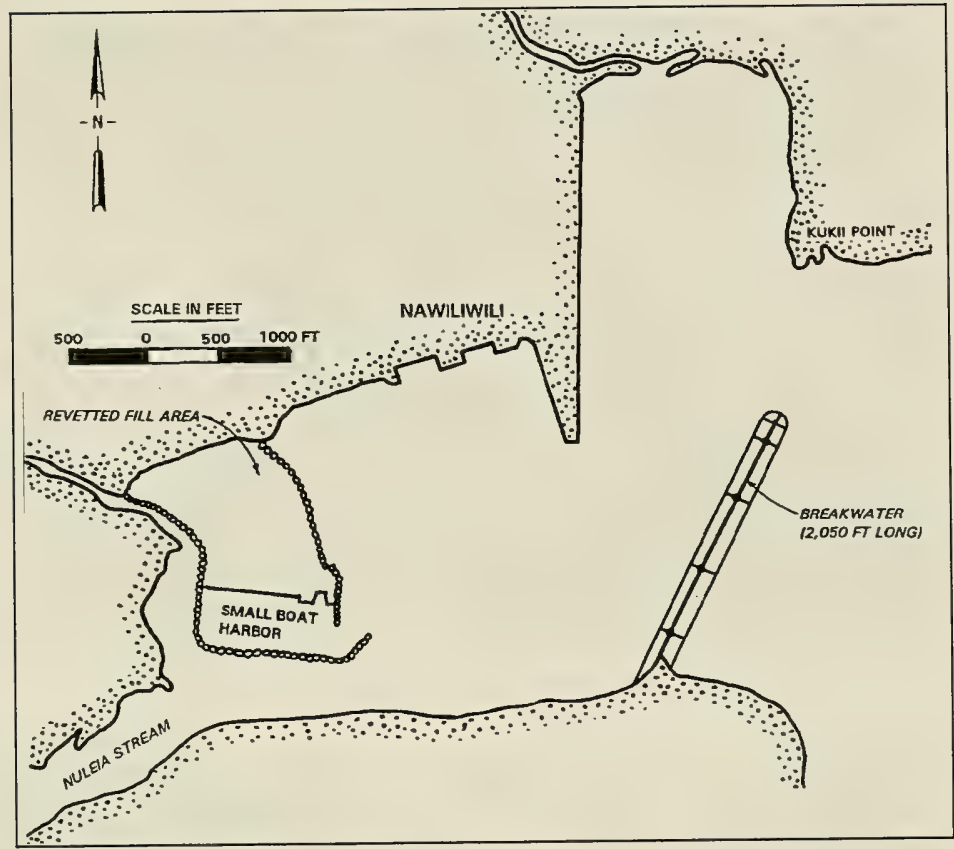

Figure 2. Layout of Nawiliwili Harbor, Kauai, HI (to convert measurements given in feet to meters, multiply by 0.305 )

The breakwater was monitored in 1995 through limited ground surveys, aerial photography, photogrammetric analysis, and a broken armor unit survey as part of the "Periodic Inspections" work unit of the MCNP program (Bottin and Boc 1996). Very accurate base level conditions for the breakwater armor units were obtained. During the monitoring, 70 broken or cracked concrete armor units were identified, and their approximate locations along the structure were documented.

The breakwater (Figure 3) was inspected on 22 July 1998. The inspection indicated that most of the armor units were in similar positions as recorded during the 1995 survey based on detailed photogrammetric maps of the structure. Numerous broken armor units were observed, but were validated as those documented in the 1995 survey. Fragments of some of the broken armor units were still in the same locations as observed in 1995. It was noted that the older $16,150-\mathrm{kg}$ (17.8-ton) tribars are showing major surface spalling of concrete (Figure 4), but this is not felt to put the structure in any danger of instability. Overall the structure is in good condition. 


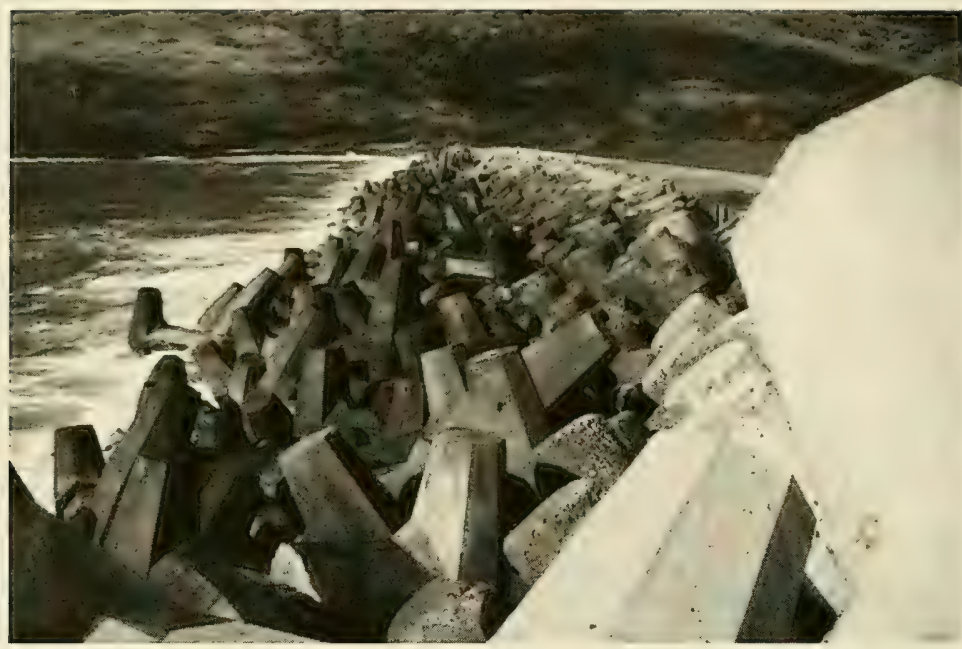

Figure 3. Sea side of Nawiliwili Harbor breakwater

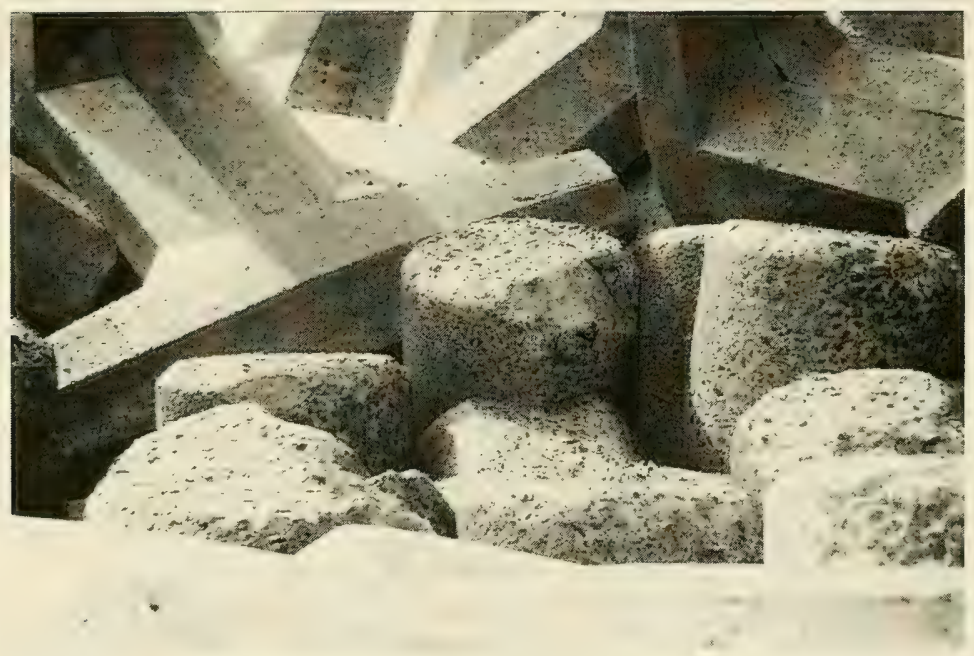

Figure 4. Surface spalling of tribars on Nawiliwili breakwater

\section{Kahului Harbor Breakwaters, Hawaii}

Kahului Harbor is located on the northern coast of the island of Maui and is the island's only deep-draft harbor. The harbor is approximately 
$150 \mathrm{~km}$ (94 miles) southeast of Honolulu. It is protected by an $843-\mathrm{m}$ long (2,766-ft-long) east breakwater and a 706-m-long (2,315-ft-long) west breakwater (Figure 5). The structures were originally constructed with a single layer of keyed and fitted, 7,260-kg (8-ton) armor stone. The breakwaters are rich in construction, repair, and rehabilitation history, and are probably the most complex in the Corps.

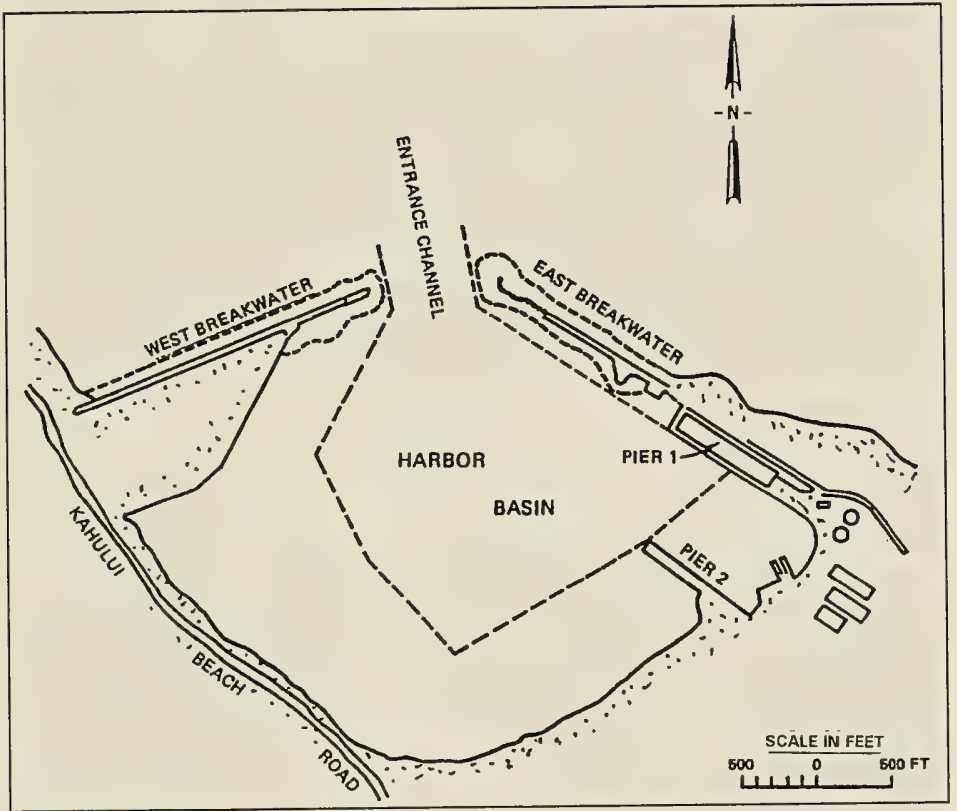

Figure 5. Layout of Kahului Harbor, Maui, HI

The harbor complex originated in 1900 when a $122-\mathrm{m}$-long (400-ftlong) east breakwater was constructed by the Kahului Railroad Company. The first involvement of the Corps with the project came in 1913 when the east breakwater was extended by $122 \mathrm{~m}(400 \mathrm{ft})$. The west breakwater was constructed to $594 \mathrm{~m}(1,950 \mathrm{ft})$ in length in 1919 , and the structures were extended to their current lengths in 1931. The first major rehabilitation was completed in 1956 on both breakwaters, and consisted of the installation of $29,940-\mathrm{kg}$ (33-ton) tetrapods and a concrete cap. The concrete armor units were placed on the heads of both breakwaters and extended $76 \mathrm{~m}(250 \mathrm{ft})$ shoreward along the sea-side face of the west breakwater trunk. In 1959, a large monolithic concrete cap and the placement of $10,885-\mathrm{kg}$ (12-ton) and larger armor stone were used to repair a breach in the east breakwater. 
Another major rehabilitation of the breakwaters occurred in 1966. Both heads and a $108-\mathrm{m}(355-\mathrm{ft})$ portion of the east structure trunk shoreward of the head were affected. The heads were armored with two layers of $31,750-\mathrm{kg}$ (35-ton) tribars on the upper one third of the slope, while the lower two thirds were protected by a double layer of $45,360-\mathrm{kg}$ ( 50 -ton) tribars. Two layers of $31,750-\mathrm{kg}(35-\mathrm{ton})$ tribars were placed from a new concrete rib cap to the toe of the rehabilitated sea-side slope of the east breakwater trunk. In 1969 , a portion of the west breakwater trunk was repaired with $17,240-\mathrm{kg}$ (19-ton) tribars and the construction of a concrete rib cap. A shoreward 24.4-m (80-ft) extension of the concrete rib cap was completed in 1973 along with the installation of additional $17,240-\mathrm{kg}$ (19-ton) tribars. The shoreward extent of these tribars was buttressed with larger tribars weighing $31,750 \mathrm{~kg}$ (35 tons).

In 1977, the following repairs were made to the structures: $27,215-\mathrm{kg}$ (30-ton) reinforced dolosse were placed in two layers over the $29,940-\mathrm{kg}$ (33-ton) tetrapods on the sea-side quadrant of the west breakwater; $18,145-\mathrm{kg}$ (20-ton) reinforced dolosse were placed on the sea side of the west breakwater trunk; 27,215-kg (30-ton) reinforced dolosse were placed in a double layer over the $29,940-\mathrm{kg}$ (33-ton) tetrapods on the sea-side quadrant of the head of the east breakwater; $18,415-\mathrm{kg}$ (20-ton) reinforced dolosse were placed in a double layer on the sea-side slope of the trunk of the east breakwater beginning shoreward of the $31,750-\mathrm{kg}$ (35-ton) tribars; and two layers of 5,445-kg (6-ton) unreinforced dolosse were placed on the sea-side slope of the east breakwater trunk.

The most recent repairs occurred in 1984 and consisted of the installation of $8,165-\mathrm{kg}$ (9-ton) tribars on the harbor side of the east breakwater over a 235-m (765-ft) distance. The concrete rib cap also was extended shoreward by $130 \mathrm{~m}(430 \mathrm{ft})$. On the west breakwater, one layer of $5,900-\mathrm{kg}$ (6.5-ton) tribars was placed on the harbor-side slope over a distance of $130 \mathrm{~m}(425 \mathrm{ft})$, and a single layer of 9,980-kg (11-ton) tribars was placed on the sea-side slope over a distance of $50 \mathrm{~m}(160 \mathrm{ft})$. A concrete rib cap was also constructed over this distance, and the $9,980-\mathrm{kg}$ (11-ton) tribars were buttressed with 22,680 -kg (25-ton) tribars.

The breakwaters at Kahului Harbor were monitored from 1991 to 1993 through limited ground surveys, aerial photography, photogrammetric analysis, and a broken armor unit survey as part of the "Periodic Inspections" work unit of the MCNP program (Markle and Boc 1994). Very accurate armor unit positions on the breakwaters were obtained during this study.

The Kahului Harbor breakwaters were inspected on 21 July 1998. The inspection, as close as could be observed visually, indicated that most of the armor unit positions were similar to those obtained during the 1993 survey. Views of the structures are shown in Figures 6 and 7 . On the east breakwater it appeared that two 31,750-kg (35-ton) tribars had flipped and slid downslope slightly on the sea side of the structure at approximately sta $10+50$. Additional breakage of some of the $5,445-\mathrm{kg}$ (6-ton) dolosse 


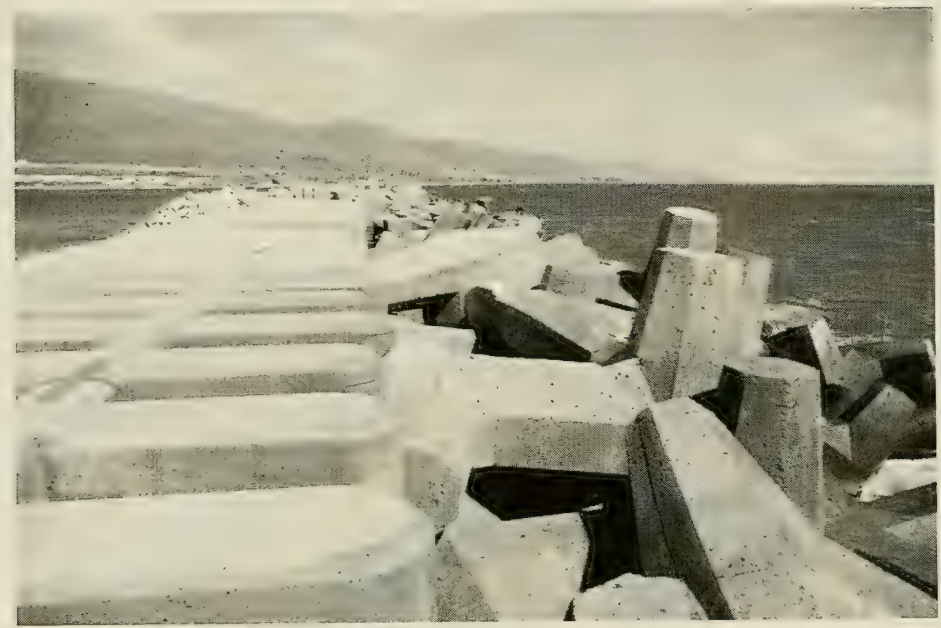

Figure 6. Kahului east breakwater

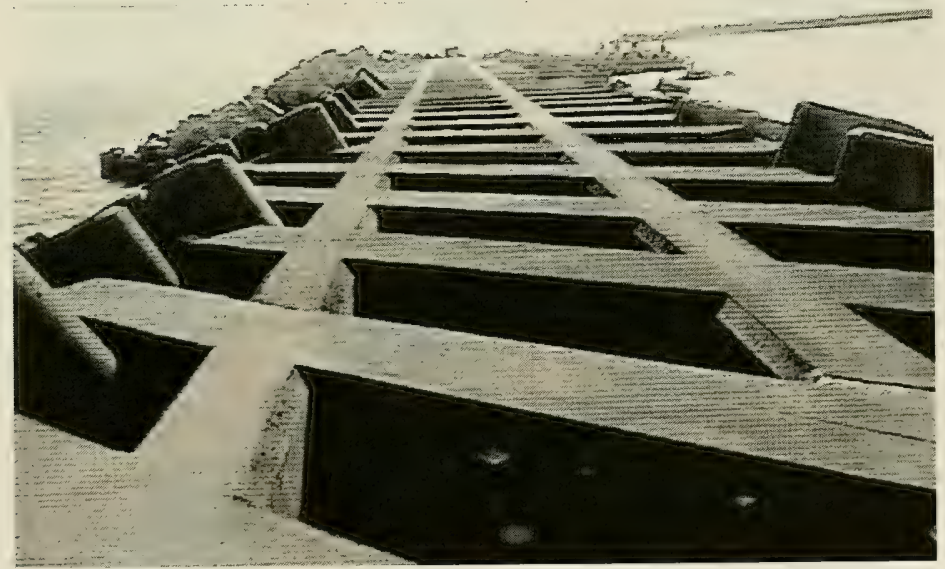

Figure 7. Kahului west breakwater

(sta $6+20$ thru $7+10$ ) on the sea side of the structure was noted since the 1993 survey. Eleven broken units were observed in this area as opposed to nine documented broken units during the 1993 survey. During the west breakwater inspection, a concentration of broken $27,215-\mathrm{kg}$ (30-ton) dolosse was noted on the sea side of the head. Twelve broken/cracked units were observed versus eleven documented during the 1993 survey. Also, some of the $5,900-\mathrm{kg}$ (6.5-ton) tribars on the harbor side of the breakwater close to its head appeared to have lifted and tilted downslope 
(possibly due to overtopping waves, Figure 8). No voids and breaches were noted in the breakwaters, and the overall condition of both structures was considered good.

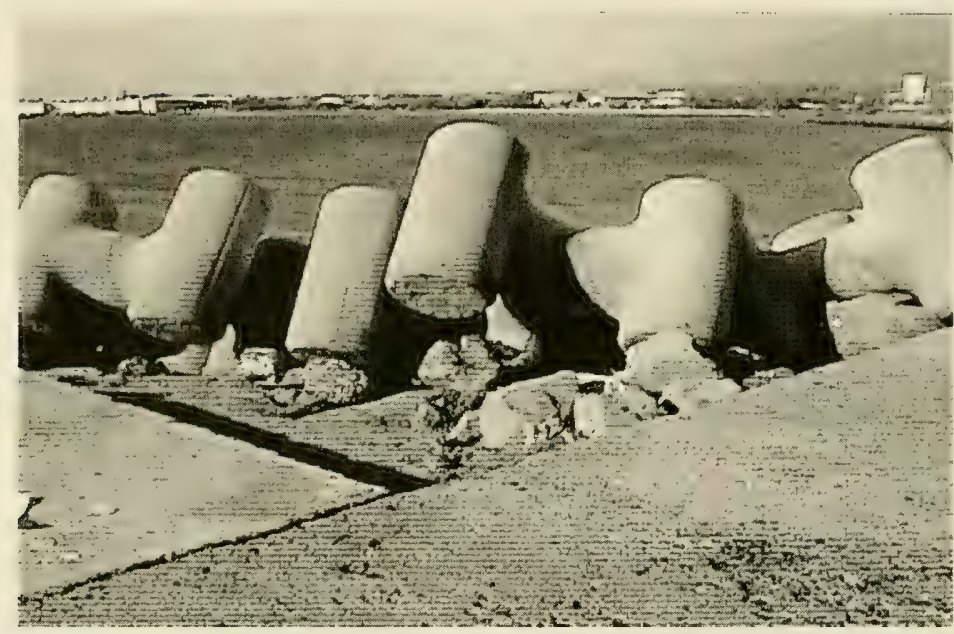

Figure 8. Tribars that appear to have tilted downslope (Kahului west breakwater)

\section{Laupahoehoe Boat-Launching Facility Breakwater, Hawaii}

Laupahoehoe is located on the north coast of the island of Hawaii approximately $40 \mathrm{~km}$ (25 miles) north-northwest of Hilo. In 1988, a 76-mlong (250-ft-long) rubble-mound breakwater was constructed that protected a 2.9 -m-deep (9.5-ft-deep) mllw entrance channel, a 2.3-m-deep (7.5-ft-deep) mllw turning basin, and a boat-launching ramp. The layout for the facility is shown in Figure 9. The breakwater is armored with two layers of $27,215-\mathrm{kg}$ (30-ton) reinforced dolosse, and the crest is stabilized with a concrete rib cap.

The breakwater was monitored from 1991 to 1993 as part of the "Periodic Inspections" work unit of the MCNP program (Markle and Boc 1994). Monitoring included limited ground surveys, aerial photography, and photogrammetric analysis. Very accurate armor unit positions were obtained during the study.

The Laupahoehoe breakwater (Figure 10) was inspected 22 July 1998. The inspection indicated that the armor units were in the same positions 


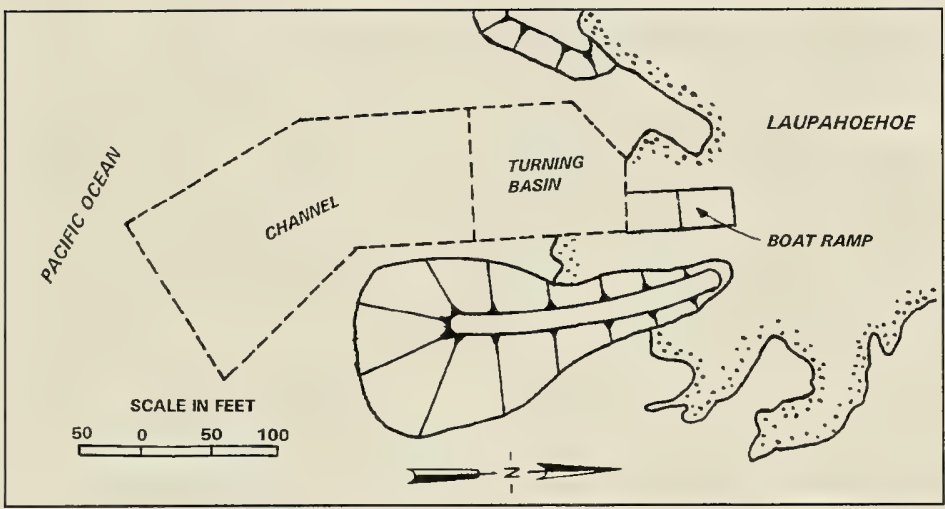

Figure 9. Layout of Laupahoehoe boat-launching facility, Hawaii, HI

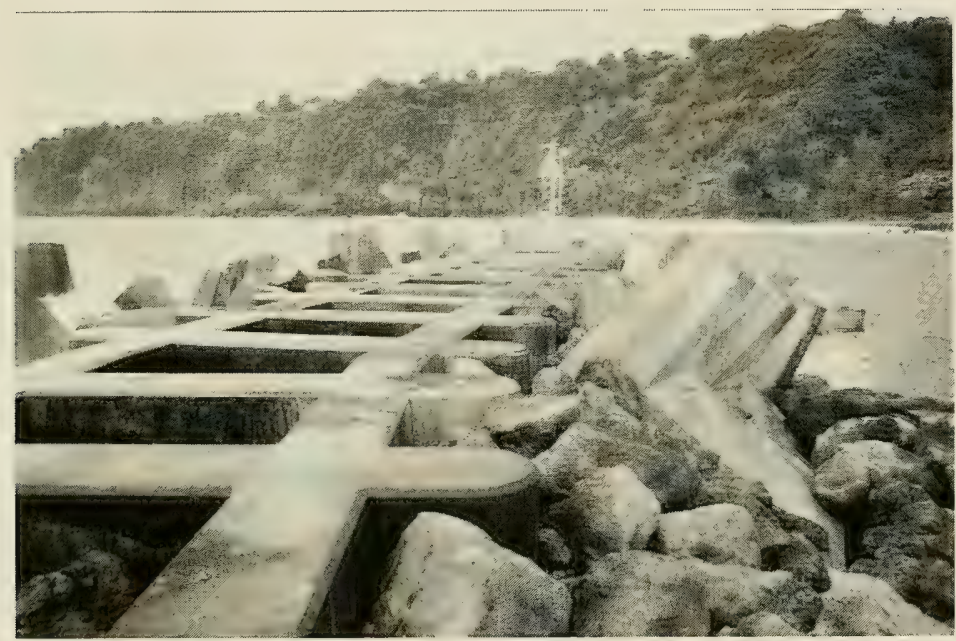

Figure 10. Laupahoehoe breakwater

as documented in the 1993 survey. No broken armor units were observed, and the structure is considered to be in excellent condition. 


\section{Yaquina Bay North Jetty, Oregon}

Yaquina Bay is a tidal estuary located on the Oregon coast approximately $177 \mathrm{~km}$ (110 miles) south of the Washington State line. The present navigation project consists of a navigation channel maintained to a depth of $-12.2 \mathrm{~m}(-40 \mathrm{ft}) \mathrm{mllw}$ at the entrance and protected by two parallel rubble-mound breakwaters, which are separated by a distance of about $305 \mathrm{~m}(1,000 \mathrm{ft})$. A layout of the project is illustrated in Figure 11.

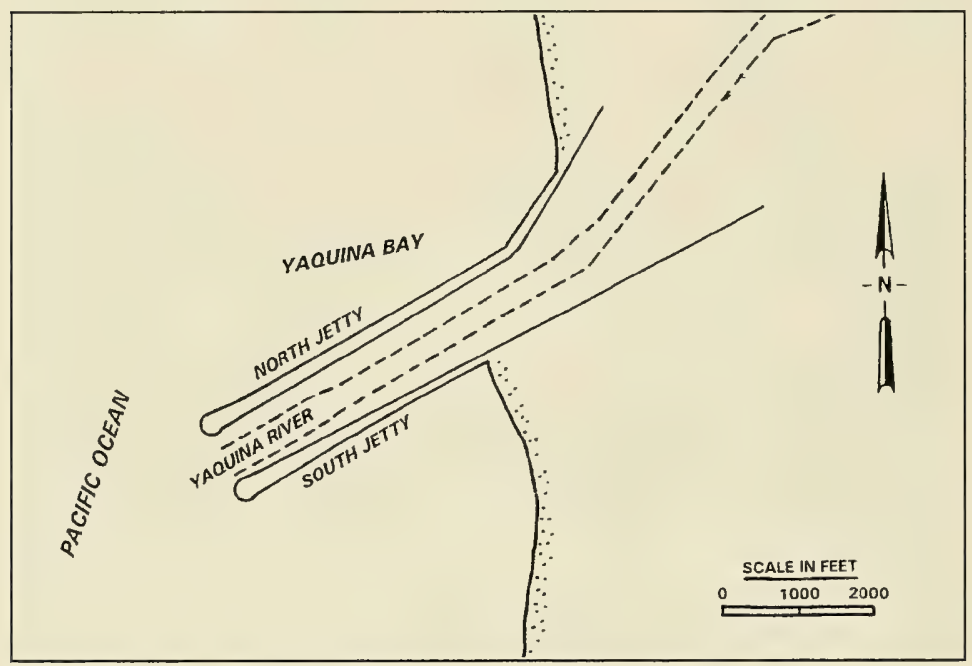

Figure 11. Layout of Yaquina Bay jetties

Since initial authorization of the Federal navigation project over 100 years ago, the two jetties protecting the entrance channel have undergone a series of extensions and repairs. The north and south jetties have been extended three times to their present authorized lengths of $2,130 \mathrm{~m}$ $(7,000 \mathrm{ft})$ and 2,620 m (8,600 ft), respectively. Since its final extension in 1972 , no additional repair work has been required on the south jetty; however, the north jetty has required two rehabilitations since its final extension in 1966. In both instances, severe wave conditions hammered the seawardmost $137 \mathrm{~m}(450 \mathrm{ft})$ of the structure below the water level, posing a hazard to navigation and creating increased dredging requirements. During the most recent repair, in 1988, the seawardmost $30.5 \mathrm{~m} \mathrm{(100} \mathrm{ft)} \mathrm{of} \mathrm{the}$ jetty was armored with $29,485-\mathrm{kg}$ (32.5-ton) stone. The next $30.5 \mathrm{~m}$ (100 ft) was armored with $23,405-\mathrm{kg}$ (25.8-ton) stone, and the landwardmost portion of the rehabilitation was armored with $16,330-\mathrm{kg}$ (18-ton)

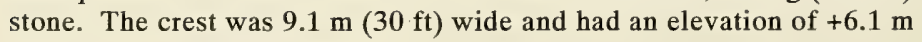
$(+20 \mathrm{ft})$. Side slopes were $1 \mathrm{~V}: 2 \mathrm{H}$. 
The troublesome history of the Yaquina Bay north jetty, coupled with some of the harshest wave conditions on the west coast of the United States, prompted the monitoring study. The jetty was monitored during the period October 1988 through September 1994 (Hughes et al. 1995). The objectives of the monitoring study were to (a) determine what mechanisms were responsible for damage that occurred at the Yaquina Bay north jetty, (b) use the study information to improve Corps of Engineers design and construction capabilities for similar harsh environments, and (c) obtain information for use in the design of a permanent repair of the north jetty. At the conclusion of the monitoring, a notch, or void region, was clearly visible on the sea side of the jetty approximately $30.5 \mathrm{~m}(100 \mathrm{ft})$ shoreward of the tip. In addition, it was apparent that stones also were missing from the sea side of the jetty tip.

An inspection of the north jetty (Figure 12) on 24 June 1997 revealed that the head of the structure no longer existed. Comparisons to photogrammetric data obtained in May 1993 indicated that approximately $50 \mathrm{~m}$ (165 ft) of the north jetty head was no longer above water, and stone had apparently been removed to below the water level by wave action. When the notch area was not visible, measurements from known locations on the structure were made to confirm this finding. Remnants of some of the jetty could be seen seaward of the structure in wave troughs as they passed. Above-water stone around the head was not uniform (Figure 13). Other observations of the structure revealed some low areas in the crest and some voids on the sea side of the jetty. At a location approximately $305 \mathrm{~m}(1,000 \mathrm{ft})$ shoreward of the jetty head (the head location of 24 June 1997), low areas in the crest existed over about a $30.5-\mathrm{m}(100-\mathrm{ft})$ span.

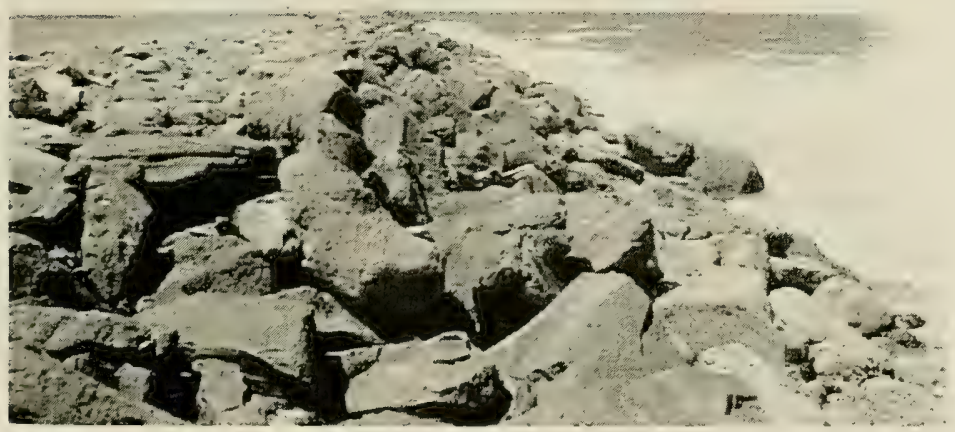

Figure 12. Yaquina Bay north jetty 


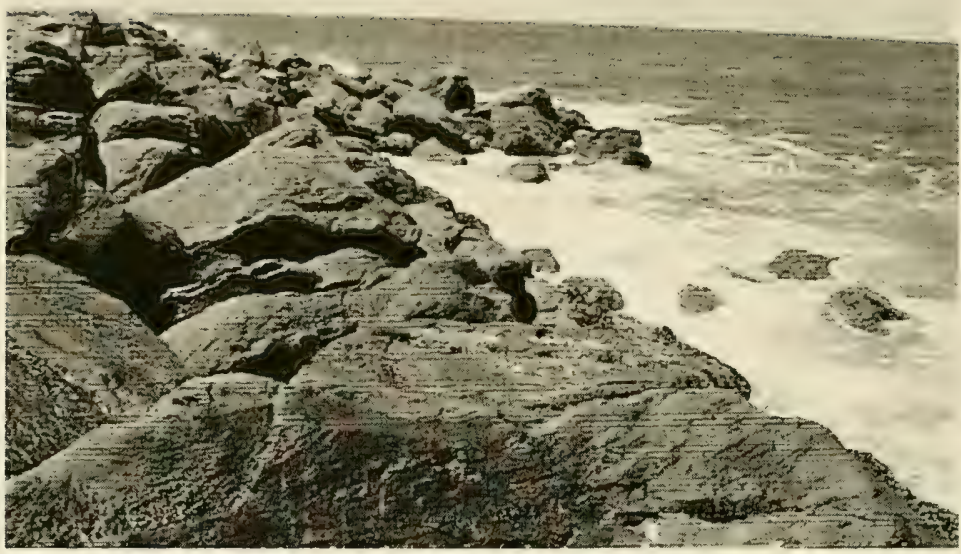

Figure 13. Head of Yaquina Bay north jetty on 24 June 1997

Another low area was observed on the crest about $520 \mathrm{~m}(1,700 \mathrm{ft})$ shoreward of the jetty head, and a void on the sea side of the jetty was observed approximately $580 \mathrm{~m}(1,900 \mathrm{ft})$ from the jetty head (Figure 14). An even larger void on the sea side of the structure was observed about $650 \mathrm{~m}(2,125 \mathrm{ft})$ shoreward of the jetty head as shown in Figure 15.

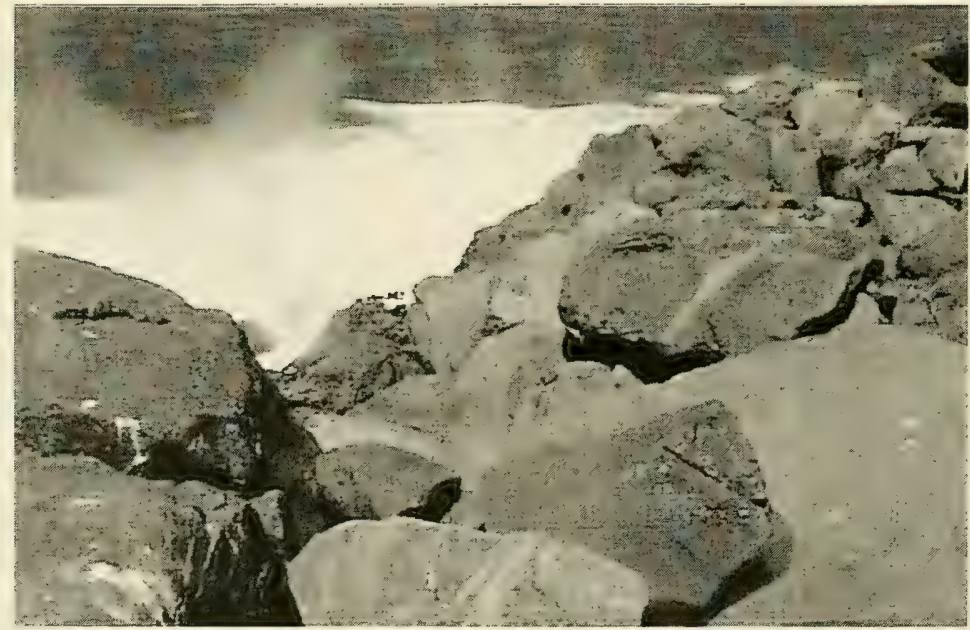

Figure 14. Void on seaward side of Yaquina north jetty observed approximately $580 \mathrm{~m}(1,900 \mathrm{ft})$ from head 


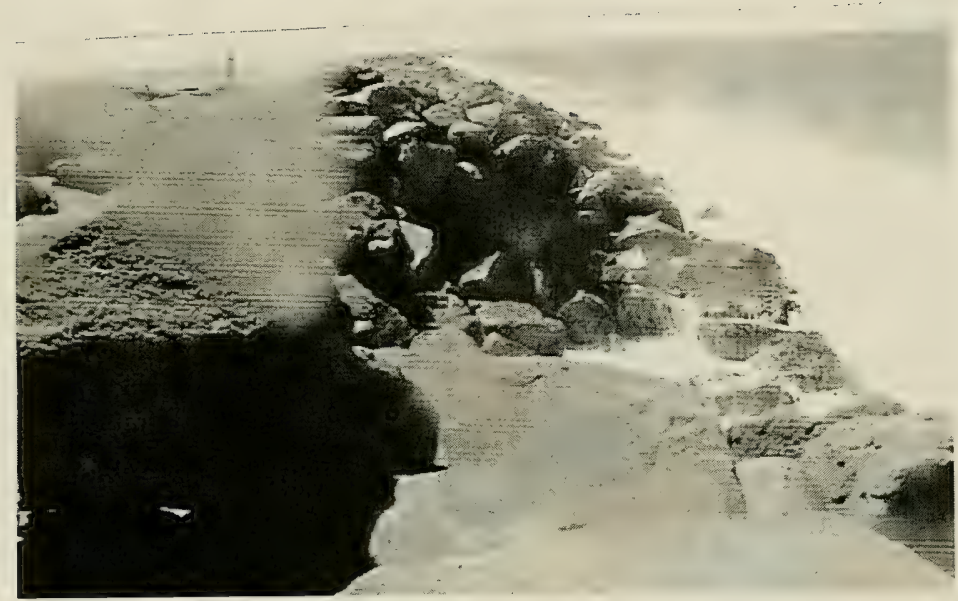

Figure 15. Void on seaward side of Yaquina north jetty observed about $650 \mathrm{~m}(2,125 \mathrm{ft})$ from head

There were additional sporadic areas along the structure crest that could use armor stones to bring the jetty back to its design cross section.

\section{Siuslaw River Jetties, Oregon}

The Siuslaw River is approximately $174 \mathrm{~km}$ (108 miles) long and enters the Pacific Ocean near the city of Florence, OR, about $250 \mathrm{~km}$ (155 miles) south of the Washington State border. Improvements for navigation at Siuslaw River began before the turn of the 20th century with the start of a jetty system by local interests. Federal participation in the project began in 1910 and consisted of two entrance jetties and a navigation channel extending upriver. The north jetty was originally $2,957 \mathrm{~m}$ $(9,700 \mathrm{ft})$ long, and the south jetty was $1,980 \mathrm{~m}(6,500 \mathrm{ft})$ long. Jetty construction was completed in 1917 . Other improvements were subsequently authorized, one of which provided for extending the jetties to the $-6.1 \mathrm{~m}$ $(-20 \mathrm{ft}) \mathrm{mllw}$ depth. In 1985 , the jetties at the mouth of the Siuslaw River were again extended seaward. The north jetty extension was $580 \mathrm{~m}$ $(1,900 \mathrm{ft})$ long, and the south jetty extension was $670 \mathrm{~m}$ (2,200 ft) long. In addition, on the ocean sides of each jetty, 122-m-long (400-ft-long) spurs oriented $45 \mathrm{deg}$ to the main structure were constructed. The spurs originated $275 \mathrm{~m}(900 \mathrm{ft})$ shoreward of the ends of the jetties. The jetty heads were located in depths of about $-7 \mathrm{~m}(-23 \mathrm{ft}) \mathrm{mllw}$. Figure 16 shows a layout of the Siuslaw River jetties and spurs. The jetty extensions and spurs were of randomly placed rubble-mound construction and were armored with stone ranging from 10,885 to $17,235 \mathrm{~kg}$ (12 to 19 tons). 


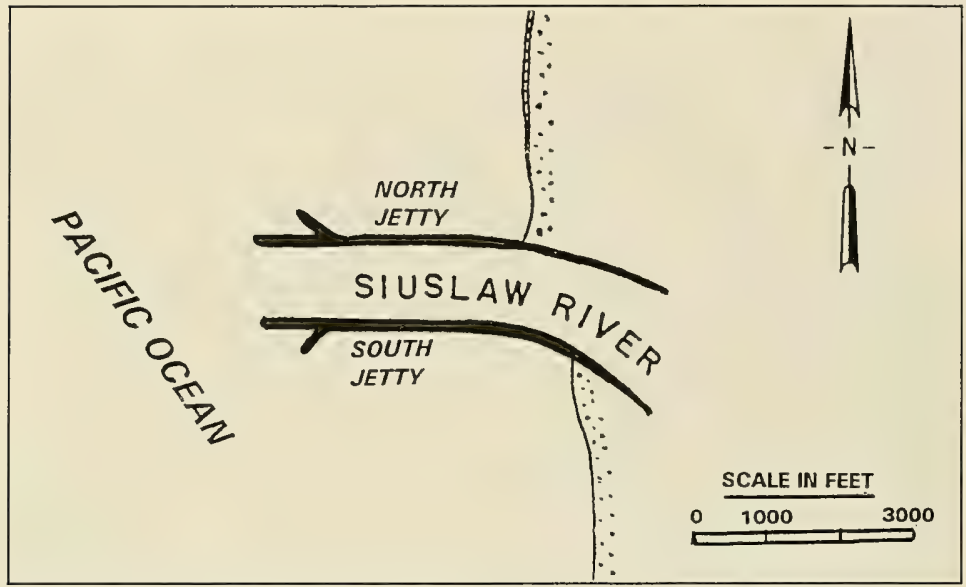

Figure 16. Layout of Siuslaw River jetties and spurs

The jetty extensions and spurs from the mouth of the Siuslaw River were monitored during the period September 1988 through September 1993 (Pollock et al. 1995). The objectives of the monitoring program were to (a) determine if the spurs effectively deflected sediment, (b) identify shoaling patterns near the jetties, (c) compare prototype conditions against those predicted by a physical model study, (d) evaluate the effectiveness of the system in reducing maintenance dredging requirements, and (e) evaluate the impact of the jetties on the surrounding beaches.

An inspection of the jetty system on 26 June 1997 revealed that some repairs were needed. On the north jetty head, a void was observed on the channel side of the structure. The area was steep, and it appeared that stone had been pulled downslope by wave action as remnants could be seen seaward of the area. About $20 \mathrm{~m}(65 \mathrm{ft})$ shoreward of the jetty head. a low area in the center of the crest existed; and approximately $27.5 \mathrm{~m}(90$ ft) from the head a void existed on the channel side of the structure. In several areas along the jetty extension, it appeared that the center portion of the crest had subsided and the elevation was irregular. The stone along the slopes, however, appeared to be up to required elevation. At a point about half the length of the jetty spur, it appeared a stone had been uplifted leaving a small void (Figure 17). With the exception of the jetty head, the slopes on the north jetty extension and jetty spur were in good condition. Inspection of the south jetty extension indicated a similar situation at the jetty head on the sea side of the structure. The slope was very steep, and it appeared that stone had been pulled downslope by wave action (Figure 18). The head of the south jetty spur also was damaged on its shoreward side as evidenced by a lack of stone above the water surface (Figure 19). In addition, immediately shoreward of the jetty spur head, a void existed on the shoreward side of the spur (Figure 20). The side 


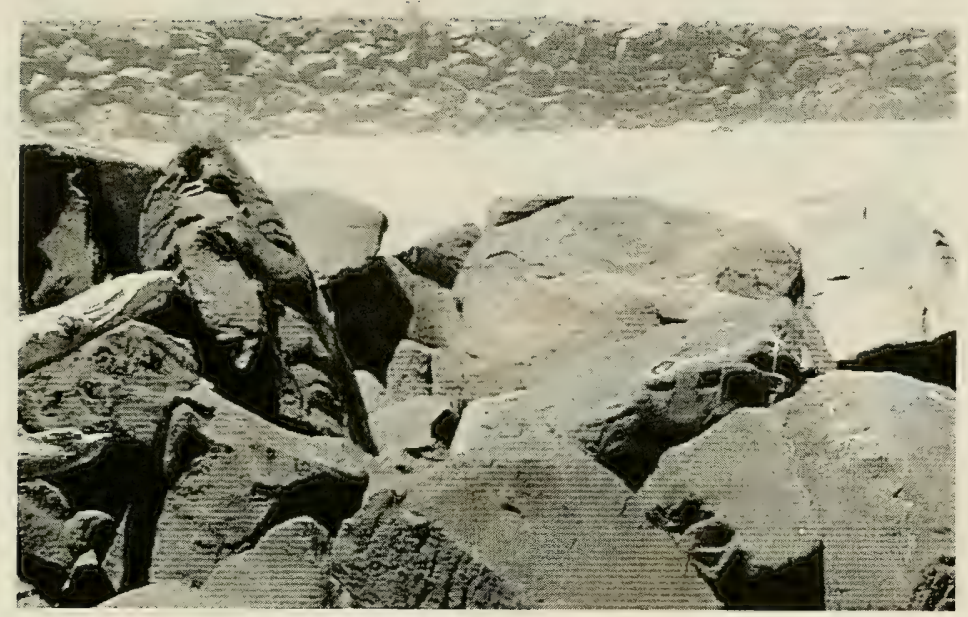

Figure 17. Displaced stone on north jetty spur at Siuslaw

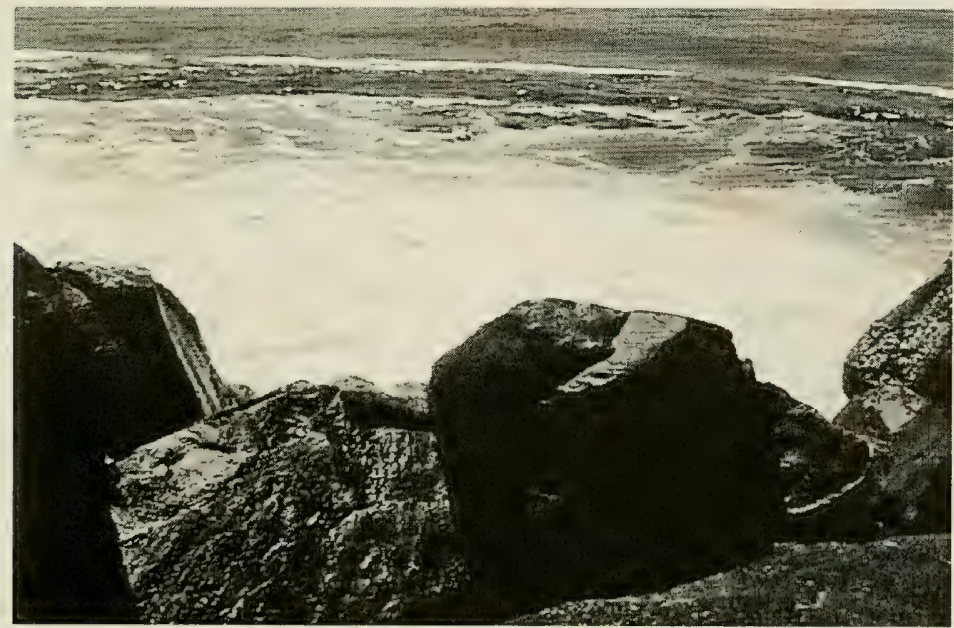

Figure 18. South jetty head at Siuslaw 


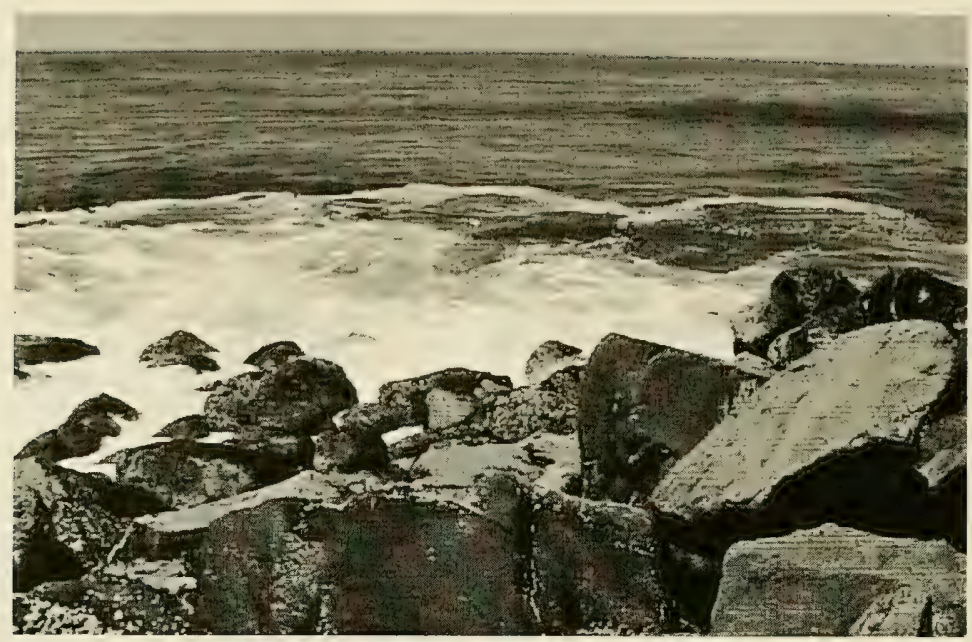

Figure 19. Head of Siuslaw River south jetty spur

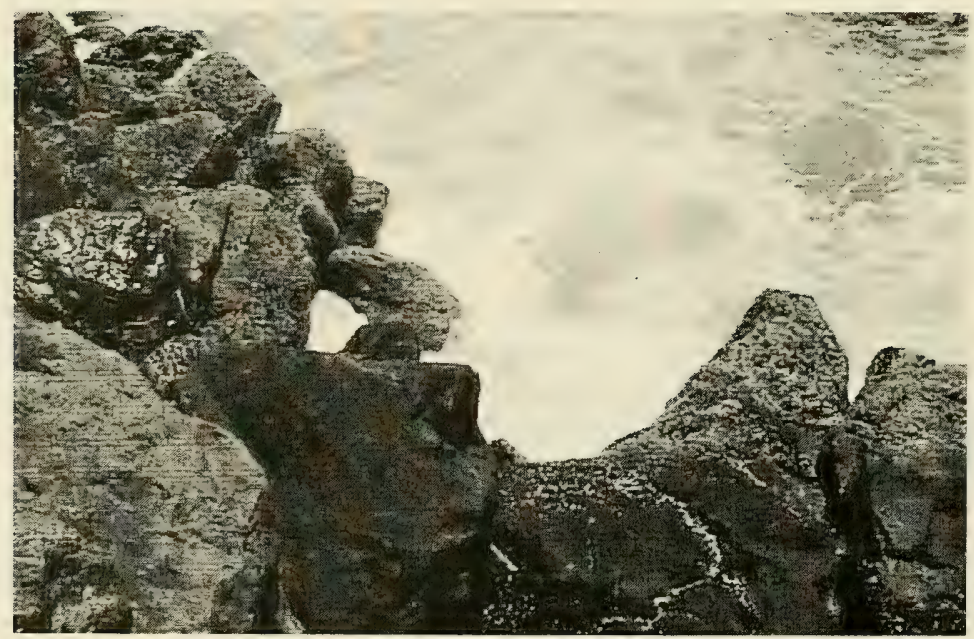

Figure 20. Void in south jetty spur at Siuslaw 
slopes of the south jetty system were in good condition, with the exception of the jetty head and the jetty spur head as previously discussed.

\section{Umpqua River Training Jetty, Oregon}

The Federal Navigation Project at the Umpqua River lies within the lower $19 \mathrm{~km}$ (12 miles) of the Umpqua River Estuary. The river entrance is located on the southern Oregon coast approximately $290 \mathrm{~km}$ (180 miles) south of the Washington State border and $650 \mathrm{~km}$ (405 miles) north of San Francisco Bay, California. Prior to navigation improvements, the river was connected to the ocean through a $275-\mathrm{m}$-wide ( 900 -ft-wide) gorge. The first major effort to improve the river entrance for navigation was the construction of a 1,035-m-long (3,390-ft-long) north jetty by local interests during the period 1916-1919. In 1930, the north jetty was extended to its present $2,440-\mathrm{m}(8,000-\mathrm{ft})$ length. A short $762-\mathrm{m}$-long $(2,500-\mathrm{ft}-$ long) south jetty was constructed in 1934 and extended to its present length of $1,280 \mathrm{~m}(4,200 \mathrm{ft})$ in 1938 . A 7.9-m-deep (26-ft-deep) mllw navigation channel, which extended upstream, also was completed in 1938. The north jetty was rehabilitated during 1941-1942, and a concrete cap was placed on the outer $1,210 \mathrm{~m}(3,975 \mathrm{ft})$. This system did not provide a satisfactory entrance due to ebb tidal currents contributing to deterioration and subsidence of the south jetty. In 1951, a 1,290-m-long (4,240-ft-long) training jetty was constructed generally parallel to the entrance channel, and in 1964 a major rehabilitation of the south jetty was completed. The training jetty was extended $790 \mathrm{~m}(2,600 \mathrm{ft})$ in 1980 to the head of the existing south jetty. In general, the training jetty paralleled the entrance channel and the north jetty. A layout of the structures is shown in Figure 21. The jetties were of randomly placed rubble-mound construction. The main jetties were armored with 9,070- to $15,420-\mathrm{kg}$ (10- to 17-ton) stone. Armor stone on the channel side of the training jetty averaged $9,070 \mathrm{~kg}$ (10 tons) and that on the embayment side averaged $2,720 \mathrm{~kg}$ ( 3 tons).

The training jetty at the mouth of the Umpqua River was monitored during the period May 1983 through May 1984 (Herndon et al. 1992). The objective of the monitoring study was to determine if the training jetty was maintaining the navigation channel as predicted by physical model studies.

The training jetty and south jetty were inspected on 25 June 1997 . Inspection of the training jetty revealed that the 1980 extension was in very good condition (Figure 22). Its cross section appeared to be uniform along its length, and very few of the armor stones had cracked. The shoreward portion of the structure (1951 construction) had some areas that appeared to be damaged on the shore side. This was prevalent immediately landward of the shoreline where stone from the back side of the jetty was scattered (Figure 23). The channel-side face of this portion of the training jetty was in good condition. Inspection of the south jetty revealed a 


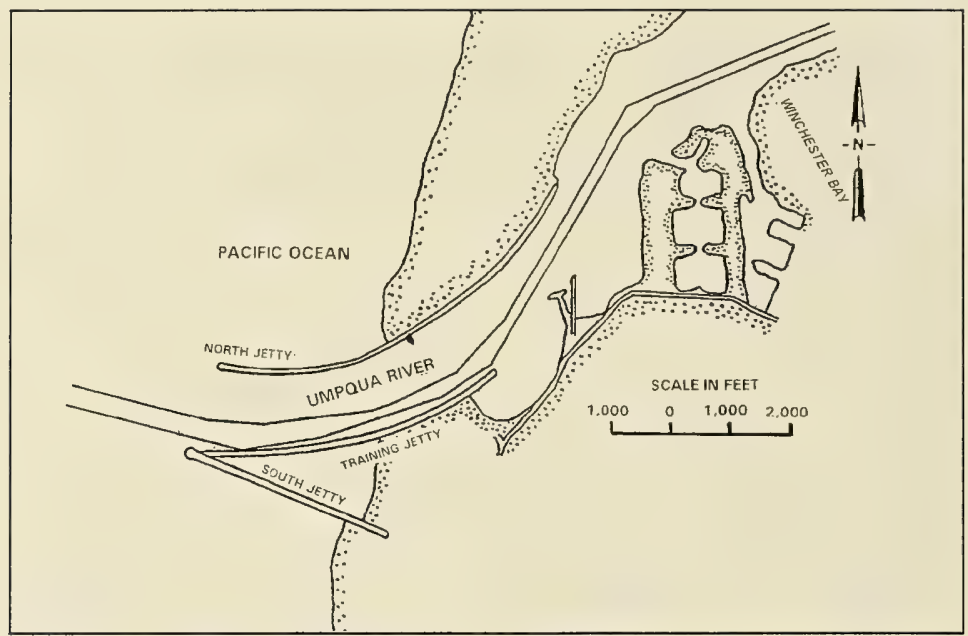

Figure 21. Layout of Umpqua River jetties

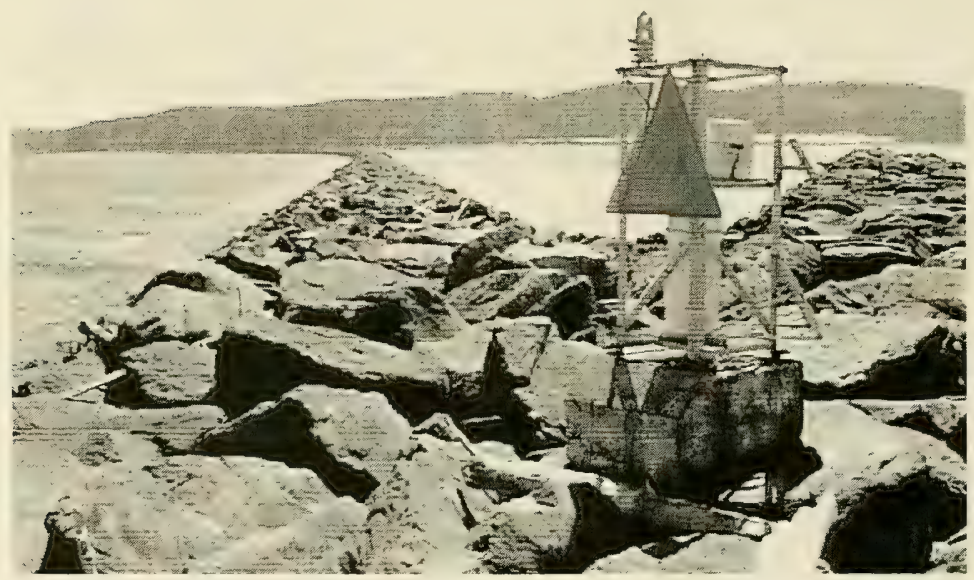

Figure 22. View of Umpqua River training jetty (left structure) looking shoreward

breach at its head. The breach did not extend below the water level, but extended through the jetty (Figure 24). In addition, just shoreward of the breach, a large void existed on the sea side of the structure (Figure 25). The trunk of the south jetty was in good condition. 


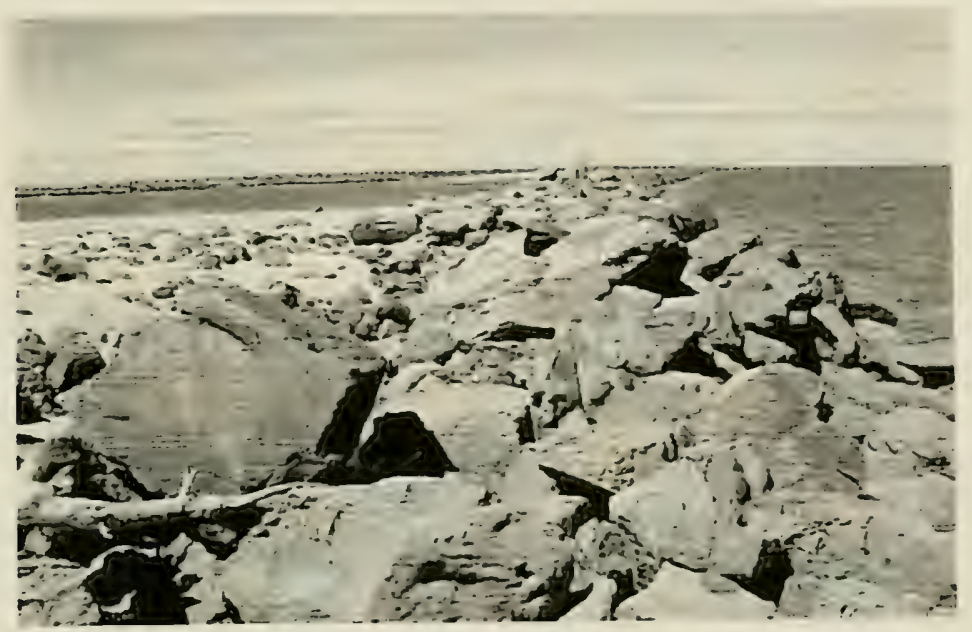

Figure 23. Scattered armor stone on shore side of Umpqua training jetty

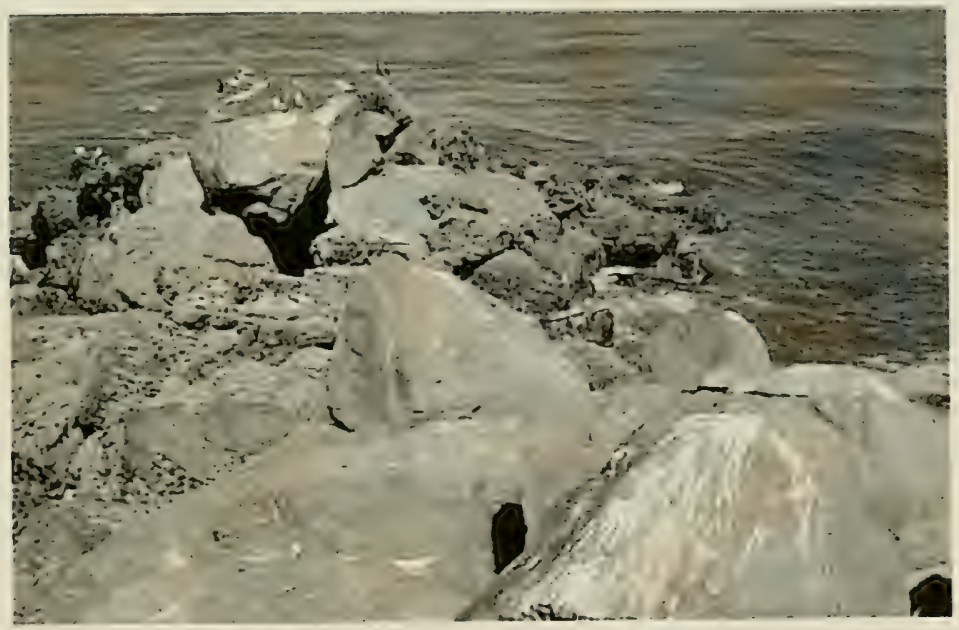

Figure 24. Breach at head of Umpqua River south jetty 


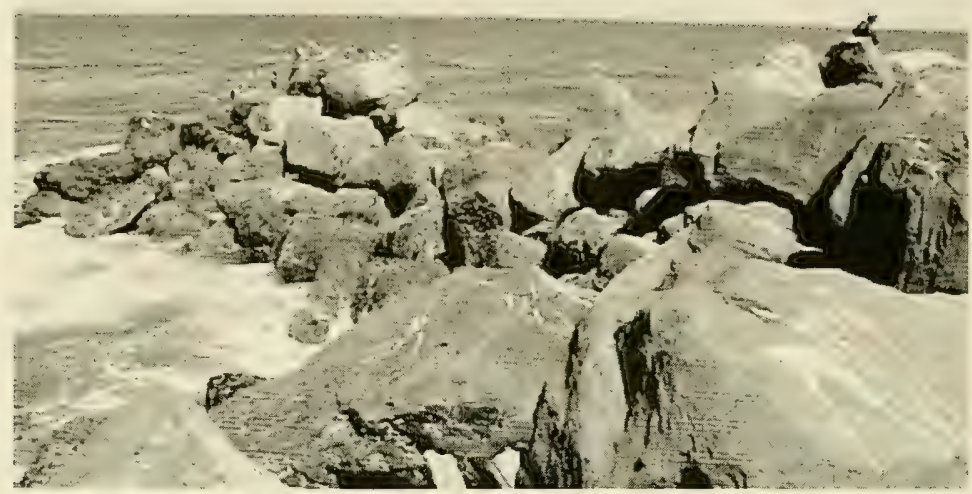

Figure 25. Breach and void at head of south jetty at Umpqua River

\section{Crescent City Harbor Breakwater, California}

Crescent City Harbor is located on the northern California coastline, approximately $27 \mathrm{~km}$ (17 miles) south of the Oregon border. The existing outer breakwater is $1,423 \mathrm{~m}(4,670 \mathrm{ft})$ in length with a $1,118-\mathrm{m}$-long (3,670-ft-long) main stem and a 305-ft-long (1,000-ft-long) easterly dogleg extension. The original project did not include the dogleg but intended for the main stem to extend to Round Rock (Figure 26). Due to severe damage sustained on the main stem beyond sta $37+00$, this option was abandoned and the dogleg was added. Original breakwater construction in 1926 consisted of $9,070-\mathrm{kg}$ (10-ton) armor stone. Due to severe damage, 22,680-kg (25-ton) unreinforced tetrapods were placed on the dogleg portion of the structure in 1964 . In $1974,36,290-\mathrm{kg}$ (40-ton) unreinforced dolosse were placed on the outer sea-side slope of the breakwater main stem (sta $34+70$ to $37+00$ ). Subsequent storms caused significant amounts of dolosse breakage; and over the years, most of the tetrapods along the elbow of the breakwater sustained breakage and/or displacement due to large breaking wave conditions. Finally, in $1989,38,100-\mathrm{kg}$ (42-ton) reinforced dolosse were placed on the sea-side slope of the main stem and along the elbow of the dogleg (sta $34+00$ to $38+05$ ).

The breakwater was monitored between November 1989 and October 1993 as part of the "Periodic Inspections" work unit of the MCNP program (Markle, Melby, and Kendall 1995). The monitoring entailed limited ground surveys, aerial photography, photogrammetric analysis, broken armor unit surveys, and static stress data recording and analysis. 


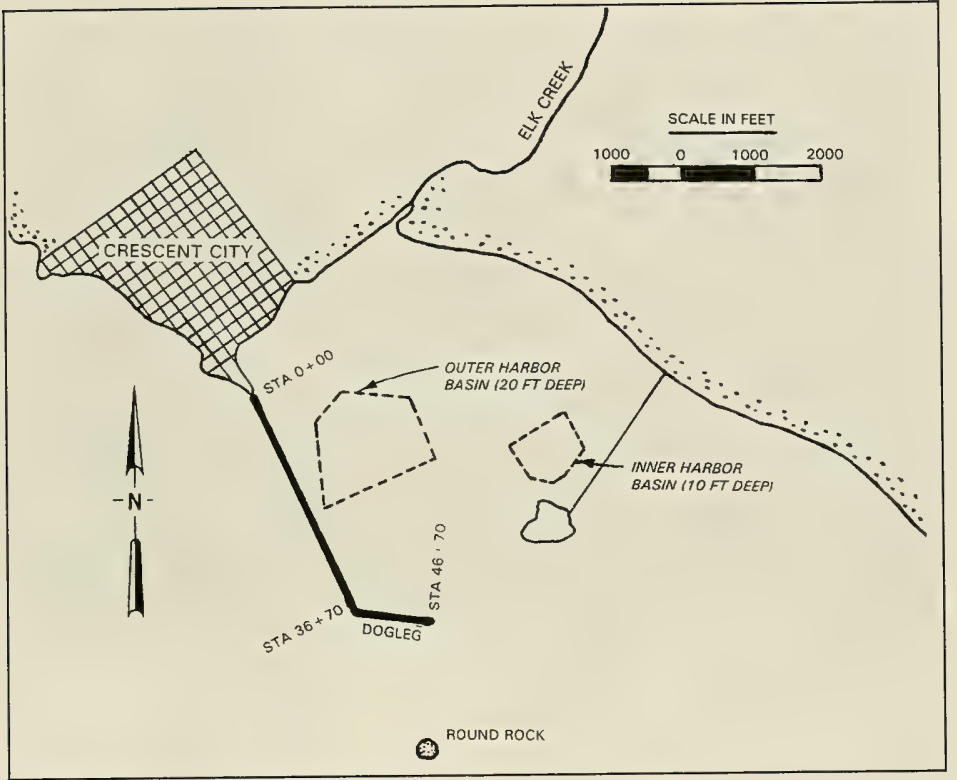

Figure 26. Layout of Crescent City Harbor, CA

Very accurate armor unit positions on the breakwater were obtained during this study.

The Crescent City Harbor breakwater (Figure 27) was inspected on 15 September 1998. The inspection indicated that most of the armor unit positions were similar to those shown in the 1993 photography as close as could be observed visually. It appeared that only a couple of the $38,100-\mathrm{kg}$ (42-ton) units had changed positions slightly along the waterline at the outer portion of the main stem. Figure 28 shows some of these units at the head of the main stem of the breakwater. Numerous broken armor units were observed, but were validated as being broken in the 1993 survey. Overall the structure is in good condition.

\section{Spud Point Marina Breakwater, California}

Spud Point Marina is located in the northwestern part of Bodega Harbor, an enclosed bay on the California coast, about $100 \mathrm{~km}$ (60 miles) north of San Francisco. Construction of the marina breakwater was completed in 1985 . The breakwater is a concrete-pile, baffled structure consisting of prestressed, vertical concrete piles and a cast-in-place concrete cap beam, with prestressed concrete baffle panels between the vertical 


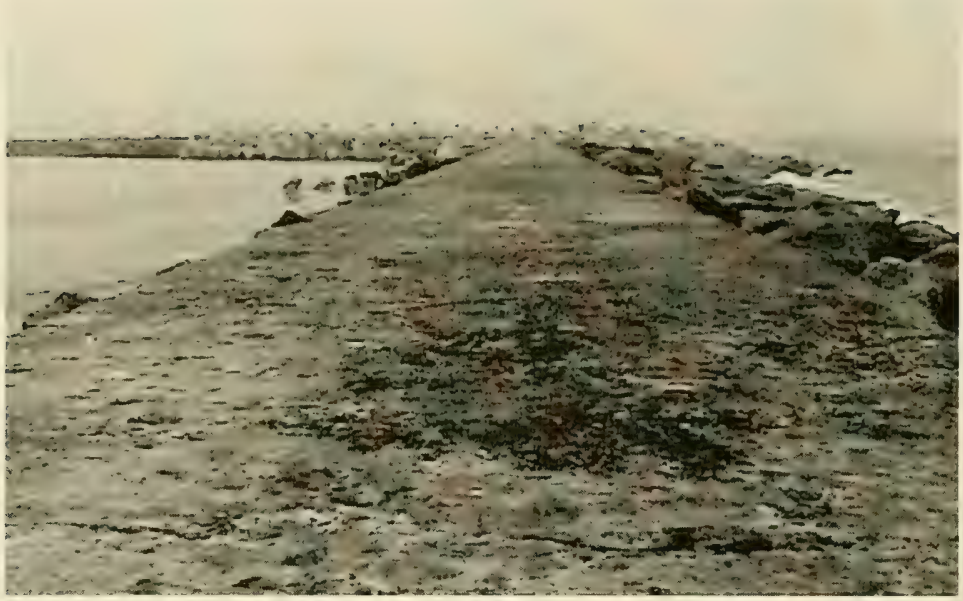

Figure 27. Crescent City Harbor breakwater

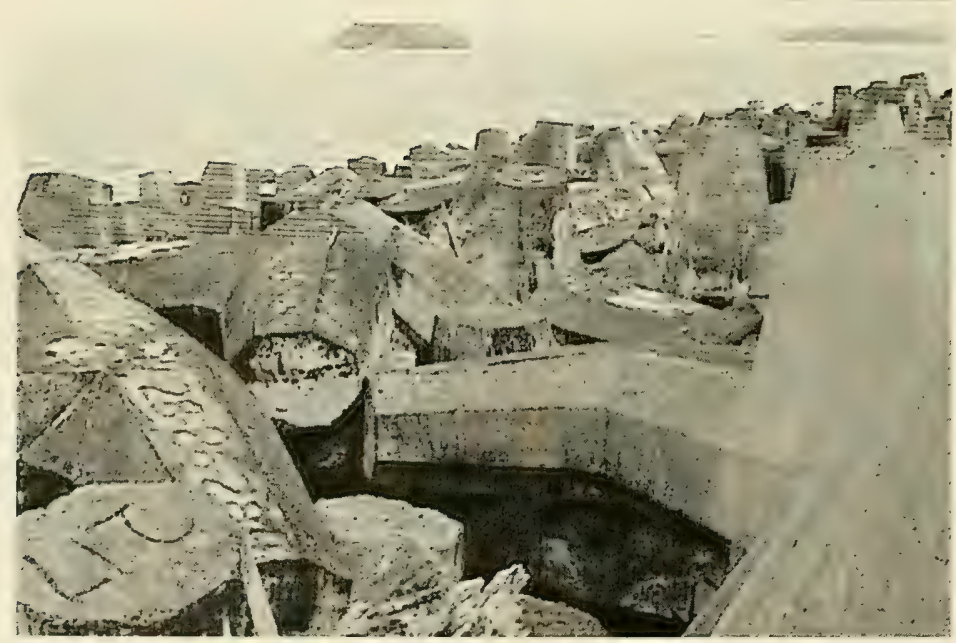

Figure 28. View of $38,100-\mathrm{kg}$ (42-ton) dolosse on the sea-side slope of the main stem of the Crescent City breakwater 
support piles under the cap beam. In addition, angled prestressed concrete batter piles are installed along the marina side of the structure giving increased lateral support. The baffle panels extend from the bottom

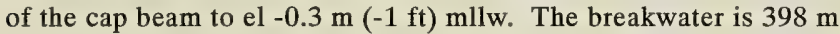
$(1,306 \mathrm{ft})$ in length and made up of a 176-m-long (576-ft-long) shoreward leg and a 222-m-long (730-ft-long) seaward section. A layout of the marina is shown in Figure 29.

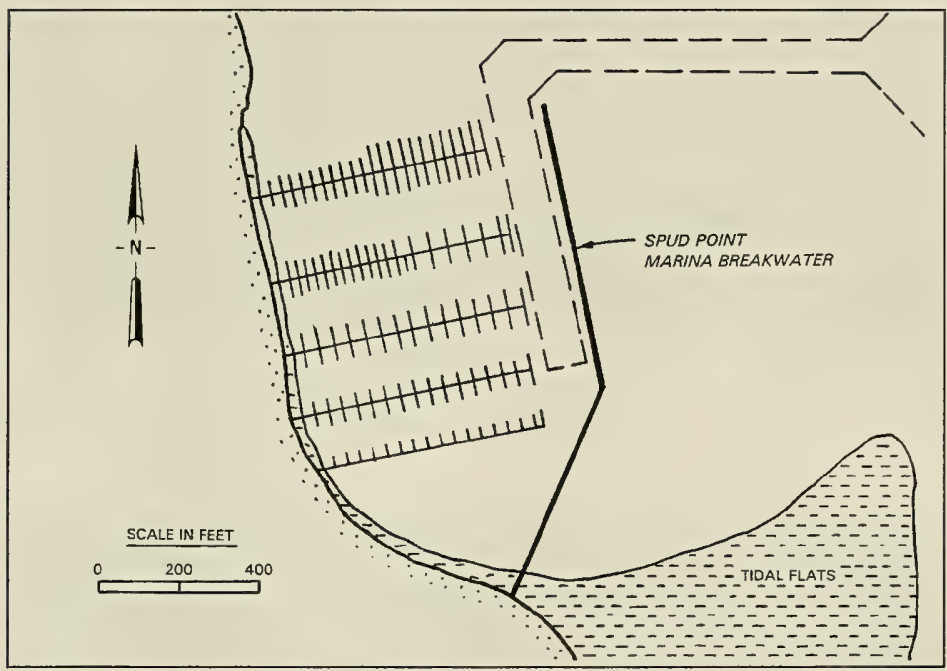

Figure 29. Layout of Spud Point Marina, CA

The Spud Point Marina site was monitored from March 1988 to February 1989 under the MCNP program (Lott 1991). The monitoring consisted of evaluating the tidal flushing characteristics of the baffled breakwater, measuring transmitted wave heights in the marina for various incident wave and tide levels, and evaluating the structural integrity of the baffled breakwater. At the conclusion of the original monitoring, it was noted that hairline cracks had formed across the width of the top of the breakwater cap in several locations, particularly where there were changes in cap width. The cracks appeared immediately after the cap was cast and were probably shrinkage related. They were considered superficial and did not affect the structural integrity of the breakwater.

The Spud Point Marina breakwater (Figure 30) was inspected on 16 September 1998. The assessment revealed no evidence of misalignment, movement, spalling, or subsidence of the structure. The hairline cracks across the top of the breakwater cap noted in the earlier surveys did not appear to have widened (Figure 31 ). Additional hairline cracks were observed, particularly on the vertical sides of the cap. Some of these cracks 


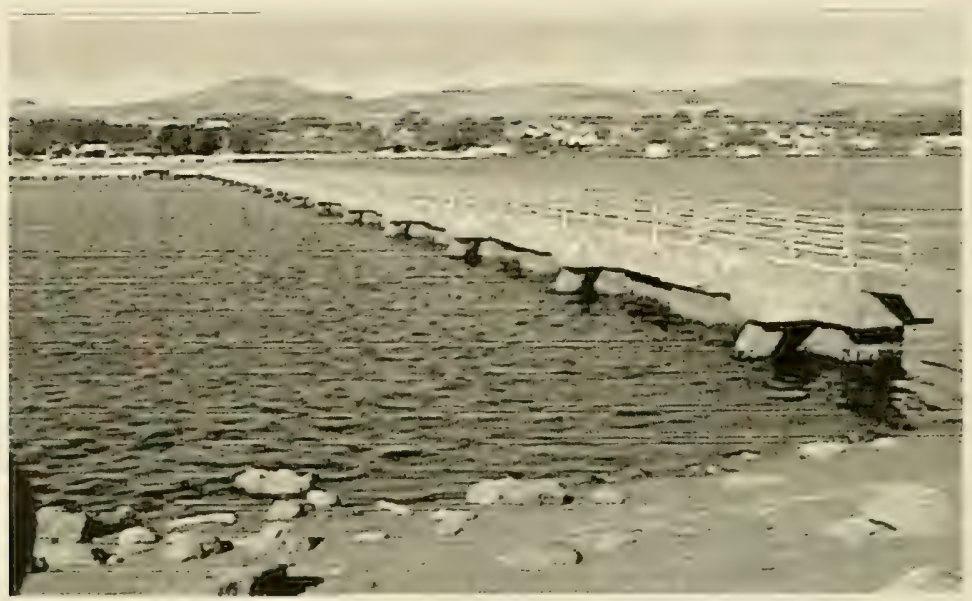

Figure 30. View of marina side of shoreward leg of Spud Point breakwater

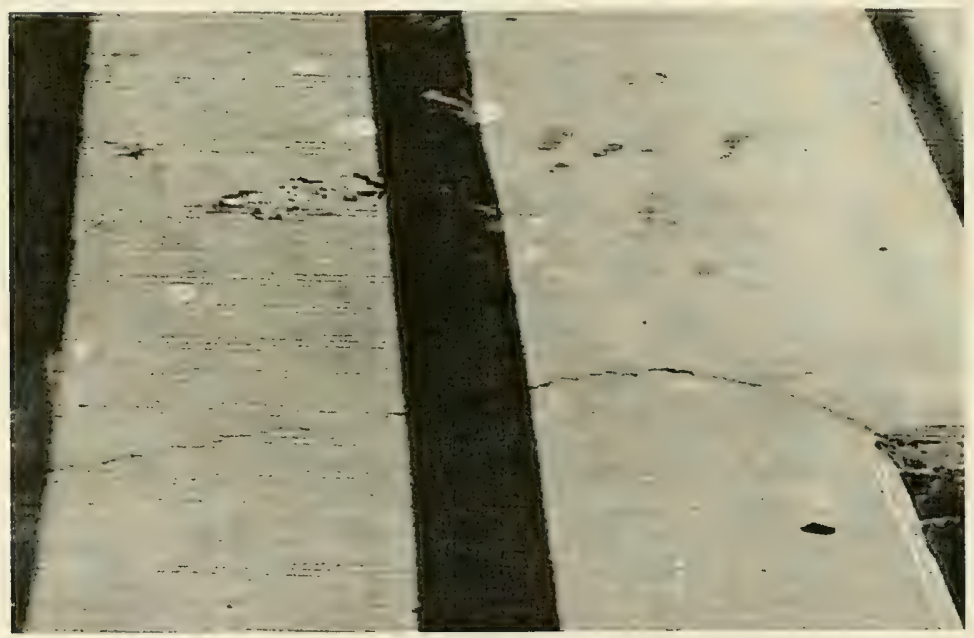

Figure 31. Hairline crack across cap of Spud Point Marina breakwater

were vertical, but the majority were horizontal cracks formed about 152 $\mathrm{mm}$ ( 6 in.) above the bottom edge (Figure 32). Stains on the concrete along some of these hairline cracks indicated that some of the rebar is rusting in these areas. Cracks along the baffled sections and batter 


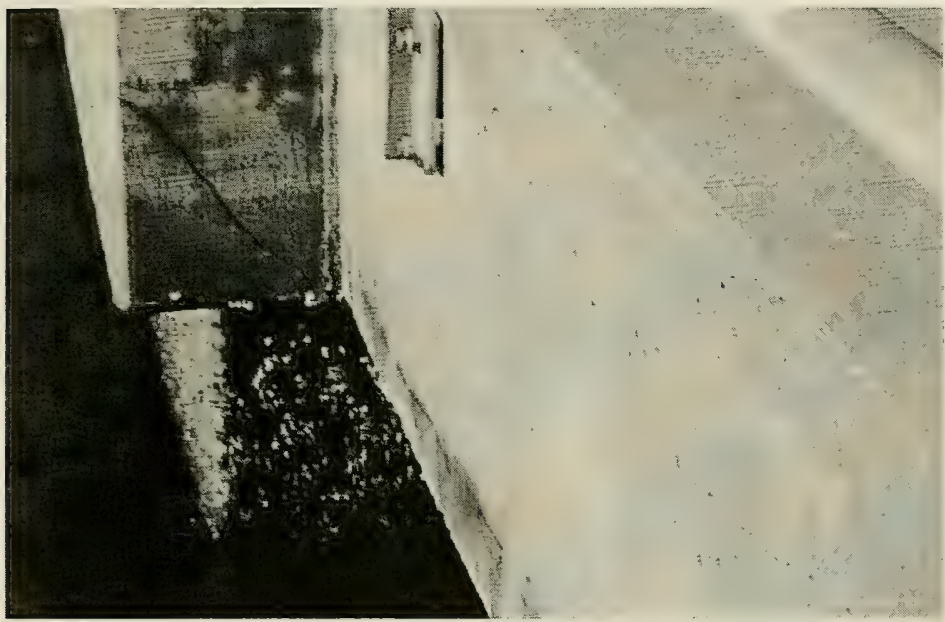

Figure 32. Example of cracks noted in vertical portions of concrete cap at Spud Point Marina breakwater

piles were not visible due to the buildup of barnacles on the structures. There is no evidence that the hairline cracks in the breakwater cap are threatening the integrity of the structures. Overall, the structure appears to be in very good to excellent condition.

\section{Fisherman's Wharf Harbor Breakwater, California}

The Fisherman's Wharf area is located in San Francisco Bay, CA, near the Golden Gate Bridge and is a well-defined segment of the San Francisco city waterfront. A breakwater system was constructed in 1986 to provide wave protection to the area. The main breakwater is $460 \mathrm{~m}$ $(1,509 \mathrm{ft})$ in length and is constructed of prestressed-precast interlocking concrete sheet piles on a curvilinear alignment. It is buttressed by inclined batter piles with a cast-in-place reinforced concrete cap tying the piles together. The breakwater system also consists of two additional interlocking sheet-pile, vertical-wall structures, but they are segmented with openings at various intervals to permit tidal circulation. These east and west segmented structures are 46 and $78 \mathrm{~m}$ (150 and $258 \mathrm{ft}$ ) in length, respectively. A layout of the harbor is shown in Figure 33.

The Fisherman's Wharf breakwaters were monitored between June 1987 and August 1991 under the MCNP program (Lott 1994). Objectives of the study were to obtain wave information in the harbor and compare it 


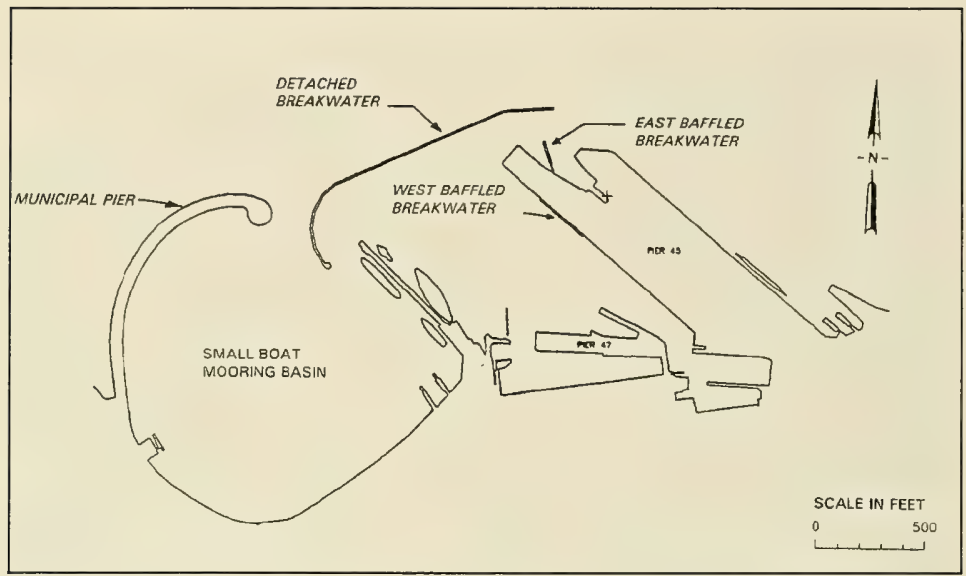

Figure 33. Layout of Fisherman's Wharf Harbor, CA

with model data; evaluate surge within the harbor as a result of the breakwater construction; evaluate the effect of the structures on water circulation; determine the effect of the structures on the littoral processes as well as measure actual scour conditions; and monitor the structural integrity of the breakwaters. At the end of the original monitoring study, no significant evidence of deterioration or changes in alignment of the structures was noted. Even after the 1989 Loma Prieta earthquake, no noticeable changes or damage were detected.

The Fisherman's Wharf breakwaters were inspected on 17 September 1998. Visual assessment of the structures was conducted by running a boat along the sides of the breakwaters and walking the main breakwater cap. A portion of the main detached breakwater is shown in Figure 34 . The inspection revealed no deterioration or apparent settlement of the breakwaters. Numerous areas along the concrete piles between the main breakwater cap and the waterline were spalled (Figure 35). These areas are not threatening the structural integrity or function of the structure. The overall condition of the breakwaters was very good to excellent.

\section{Burns Harbor Breakwater, Indiana}

Burns Harbor, Indiana, is located on the southern shoreline of Lake Michigan, approximately $32 \mathrm{~km}$ (20 miles) southeast of Chicago, IL. Breakwater construction at the site was completed in 1968, and harbor dredging was completed in 1970. The Burns Harbor structure includes a 1,415-m-long (4,640-ft-long) rubble-mound north breakwater with an east-west alignment, a 365-m-long (1,200-ft-long) rubble-mound 


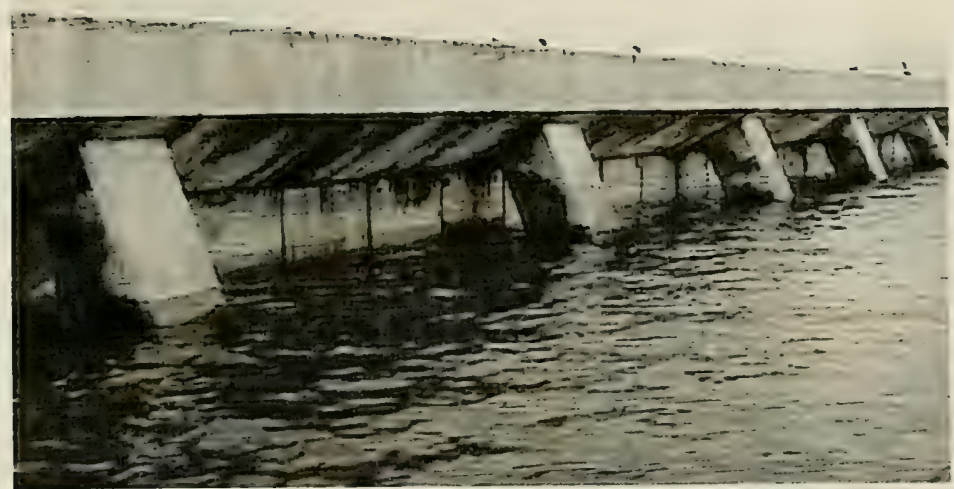

Figure 34. Portion of detached breakwater at Fisherman's Wharf Harbor

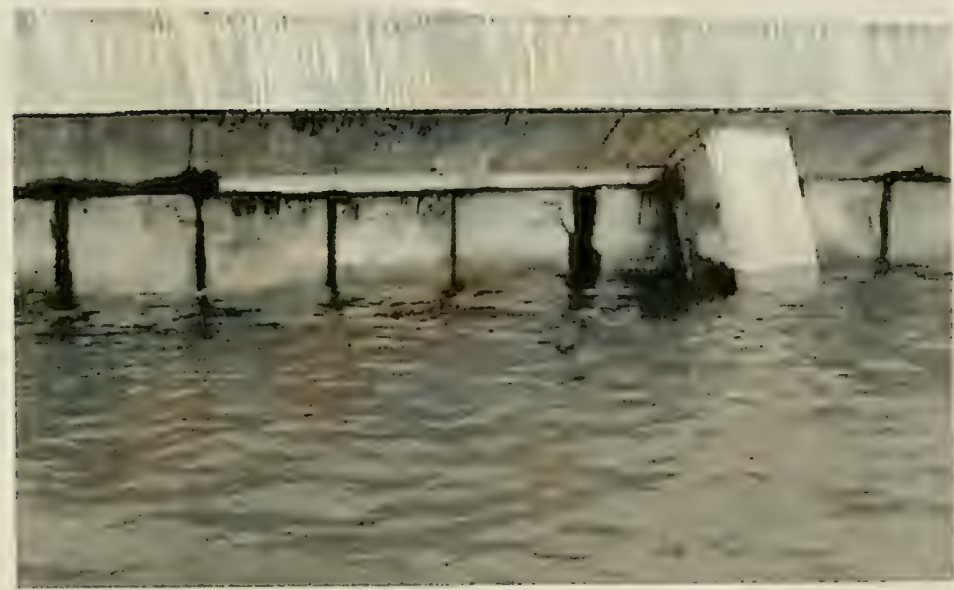

Figure 35. Spalling of concrete piles between the breakwater cap and the water surface at Fisherman's Wharf Harbor

breakwater with a north-south alignment, and a cellular steel sheet-pile extension connecting the west breakwater to shore. A layout of the harbor is shown in Figure 36. 


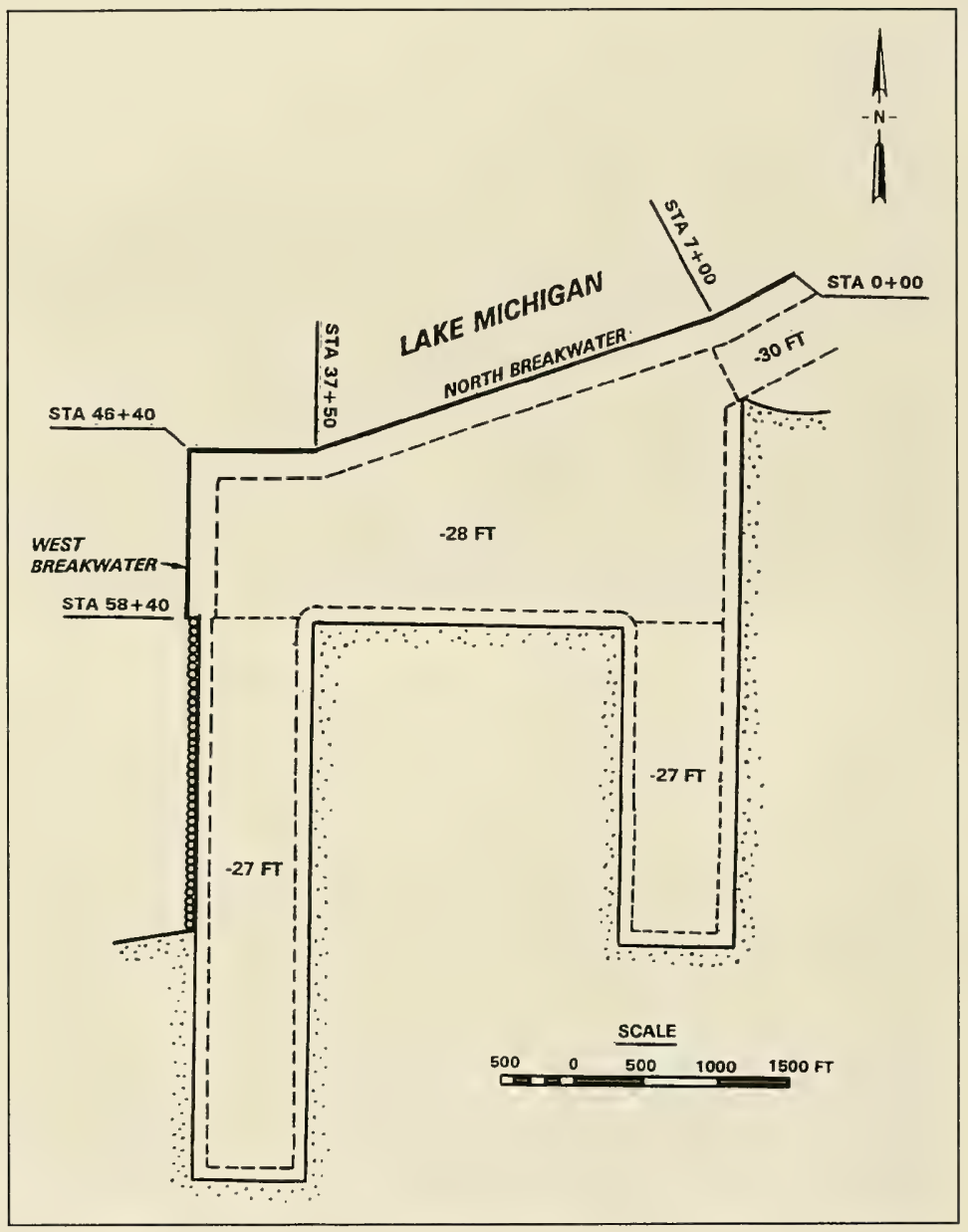

Figure 36. Layout of Burns Harbor, IN

The rubble-mound breakwater was constructed with a multilayered design and random placement of the armor stone cover layer. The crest elevation was $+4.3 \mathrm{~m}(+14 \mathrm{ft}$ ) low-water datum (lwd). Armor stones consisted of rectangular-cut Indiana Bedford limestone blocks ranging from 9,100 to $13,600 \mathrm{~kg}$ (10 to 15 tons) on the trunk and 13,600 to $18,100 \mathrm{~kg}$ (15 to 20 tons) on the head. Since completion of construction, extensive breakwater damage has occurred. In the first 19 years of operation, an average of $693,100 \mathrm{~kg}(7,640$ tons) of stone per year was placed on the breakwater. Between 1975 and 1989, the total amount of maintenance stone placed on the structure was $131,647,900 \mathrm{~kg}(145,117$ tons $)$, 
representing 54 percent of the entire armor layer stone. The harbor-side and lake-side portions of the breakwater received approximately the same proportions of stone. Burns Harbor was originally monitored during the period 1985 through 1989; however, detailed, quantifiable positions of the above-water breakwater armor stone were not obtained. The effort studied structural stability, geotechnical stability, and waves and water levels (McGehee et al. 1997). Data collection included site inspections, dive inspections, side-scan sonar surveys, geotechnical data, and wave and water level data. The north breakwater was monitored under the "Periodic Inspections" work unit of the MCNP program from November 1994 through July 1995. Monitoring consisted of limited ground surveys, aerial photography, photogrammetric analysis, and a broken armor unit survey (Bottin and Matthews 1996). Detailed topography of the above-water portion of the structure was obtained as well as cross sections along the structure at numerous locations.

The Burns Harbor north breakwater (Figures 37 and 38) was inspected on 17 June 1998. The elevation of the breakwater was compared to topography data obtained previously during the photogrammetric analysis. Sections of the structure in which it appeared that low areas existed since the last inspection are shown in the following tabulation.

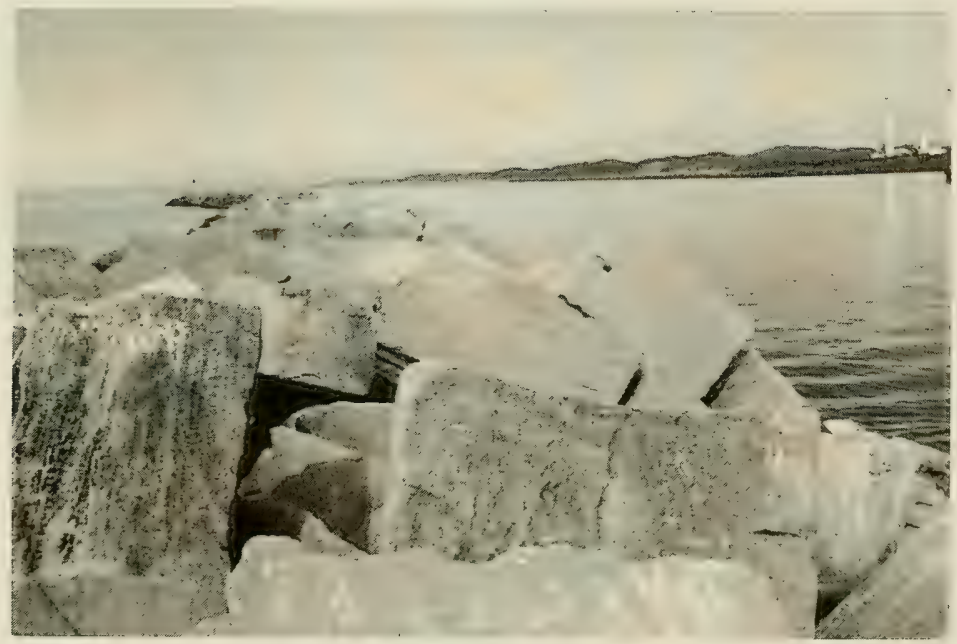

Figure 37. Burns Harbor breakwater looking east 


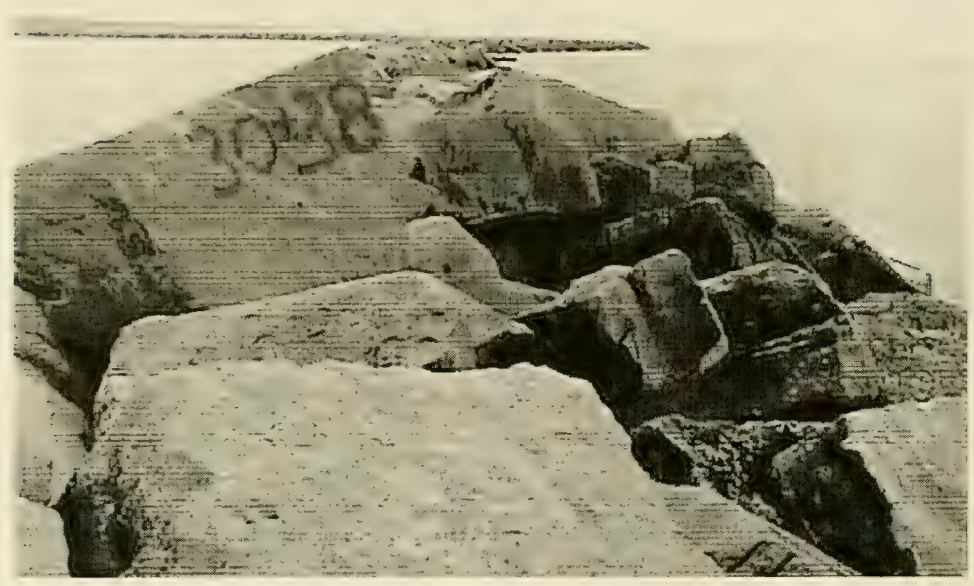

Figure 38. Burns Harbor breakwater looking west

\begin{tabular}{||l|l|l|l|}
\hline Station & Harbor Side & Crest & Lake Side \\
\hline $7+50$ & & $X$ & $X$ \\
\hline $9+20$ & & $X$ & \\
\hline $9+60$ & $X$ & & \\
\hline $11+65$ & & $X$ & \\
\hline $12+25$ & $X$ & $X$ & \\
\hline $14+40$ & & $X$ & \\
\hline $15+20$ & & & \\
\hline $18+30$ & $X$ & & $X$ \\
\hline $22+00$ & & $X$ & \\
\hline $24+00$ & & $X$ & $X$ \\
\hline $24+30$ & & $X$ & \\
\hline $24+60$ & & $X$ & \\
\hline $26+50$ & & $X$ & \\
\hline $29+35$ & & $X$ & \\
\hline $30+45$ & & $X$ & \\
\hline $31+40$ & & $X$ & \\
\hline $35+70$ & & $X$ & \\
\hline $41+15$ & & $X$ & \\
\hline
\end{tabular}


The inspection also indicated several voids in the breakwater. Figures 39 and 40 depict typical voids in the Burns Harbor structure. It appeared that continued deterioration of the breakwater had occurred since the last inspection.

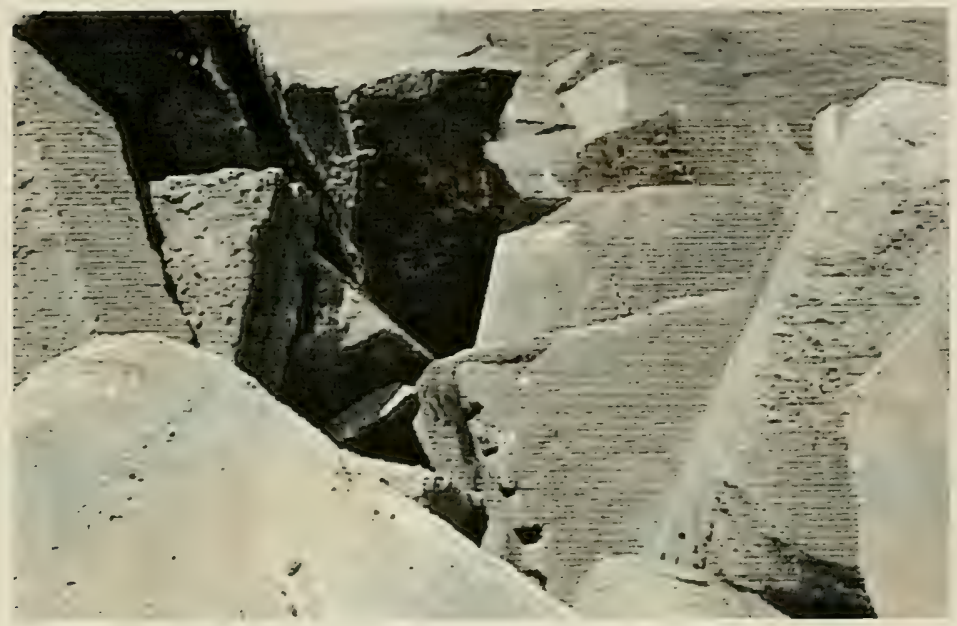

Figure 39. Void on lakeward crest of Burns Harbor breakwater

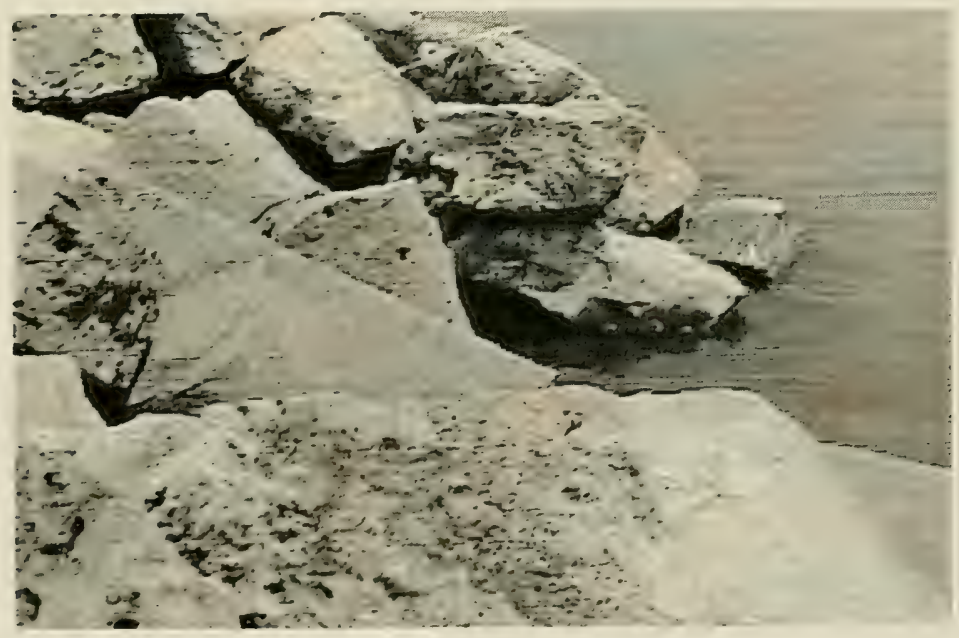

Figure 40. Typical void in harbor side of Burns Harbor breakwater 
It was noted during the inspection, however, that a barge was working lakeward of the north breakwater. Construction of a submerged, offshore reef breakwater was ongoing. The submerged reef was designed to reduce wave heights at the north breakwater during storms, thus resulting in less structure damage as well as decreased wave heights in the harbor. Construction of the reef breakwater was scheduled to be completed in the fall of 1998.

\section{Cleveland Harbor East Breakwater, Ohio}

Cleveland Harbor, Ohio, is located on the southern shore of Lake Erie, $154 \mathrm{~km}$ (96 miles) east of Toledo, $\mathrm{OH}$, and $283 \mathrm{~km}$ (176 miles) west of Buffalo, NY. The harbor is situated at the mouth of the Cuyahoga River and comprises approximately $5.3 \mathrm{sq} \mathrm{km} \mathrm{(1,300} \mathrm{acres).} \mathrm{Cleveland} \mathrm{Harbor}$ is protected by a breakwater system over $9,144 \mathrm{~m}(30,000 \mathrm{ft})$ in aggregate length. Two harbor entrances connect the harbor with Lake Erie. The west entrance is directly lakeward of the Cuyahoga River mouth, and the east entrance is at the eastern end of the east breakwater. A layout of the harbor is shown in Figure 41.

The length of the existing east breakwater is $6,392 \mathrm{~m}(20,970 \mathrm{ft})$. The westerly $914-\mathrm{m}$-long (3,000-ft-long) portion was constructed between 1887 and 1900 , and was composed of a stone-filled timber crib structure with a concrete cap. During the period 1917-1926, a stone superstructure including a sloping stone armoring was placed on the lakeward side. The easterly 5,477-m (17,970-ft) portion was constructed between 1903 and 1915 and consisted of dumped core stone covered with large individually placed armor stone. The breakwater had a design crest el of $+3.14 \mathrm{~m}$ $(+10.3 \mathrm{ft})$ lwd and a crest width of $3.05 \mathrm{~m}(10.0 \mathrm{ft})$.

The east breakwater has had an extensive repair history. Storm damage has caused the displacement of laid-up cover stone, especially on the lake side, resulting in continuous unravelling of the breakwater slope in many areas. The structure was repaired by rebuilding the damaged portion in a manner similar to original construction using $2,722-$ to $7,257-\mathrm{kg}$ (3- to 8-ton) stone. A major rehabilitation project involving the easterly $1,341 \mathrm{~m}(4,400 \mathrm{ft})$ of the east breakwater was completed in 1979 (Figure 41). It involved repairing the structure with dolos concrete armor units. The lakeward slope and in some areas the crest were rebuilt using 1,814-kg (2-ton) dolosse placed on a $1 \mathrm{~V}: 2 \mathrm{H}$ slope on the breakwater trunk. The east head involved a section similar to the trunk, but the slope was constructed on a $1 \mathrm{~V}: 2.5 \mathrm{H}$ slope to maintain stability. This was the first use of dolosse on an offshore structure in the Great Lakes environment in the United States.

The rehabilitated dolos section was monitored under the MCNP program during the period November 1980 through September 1985 (Pope, Bottin, and Rowen 1993). The monitoring program was to evaluate the 


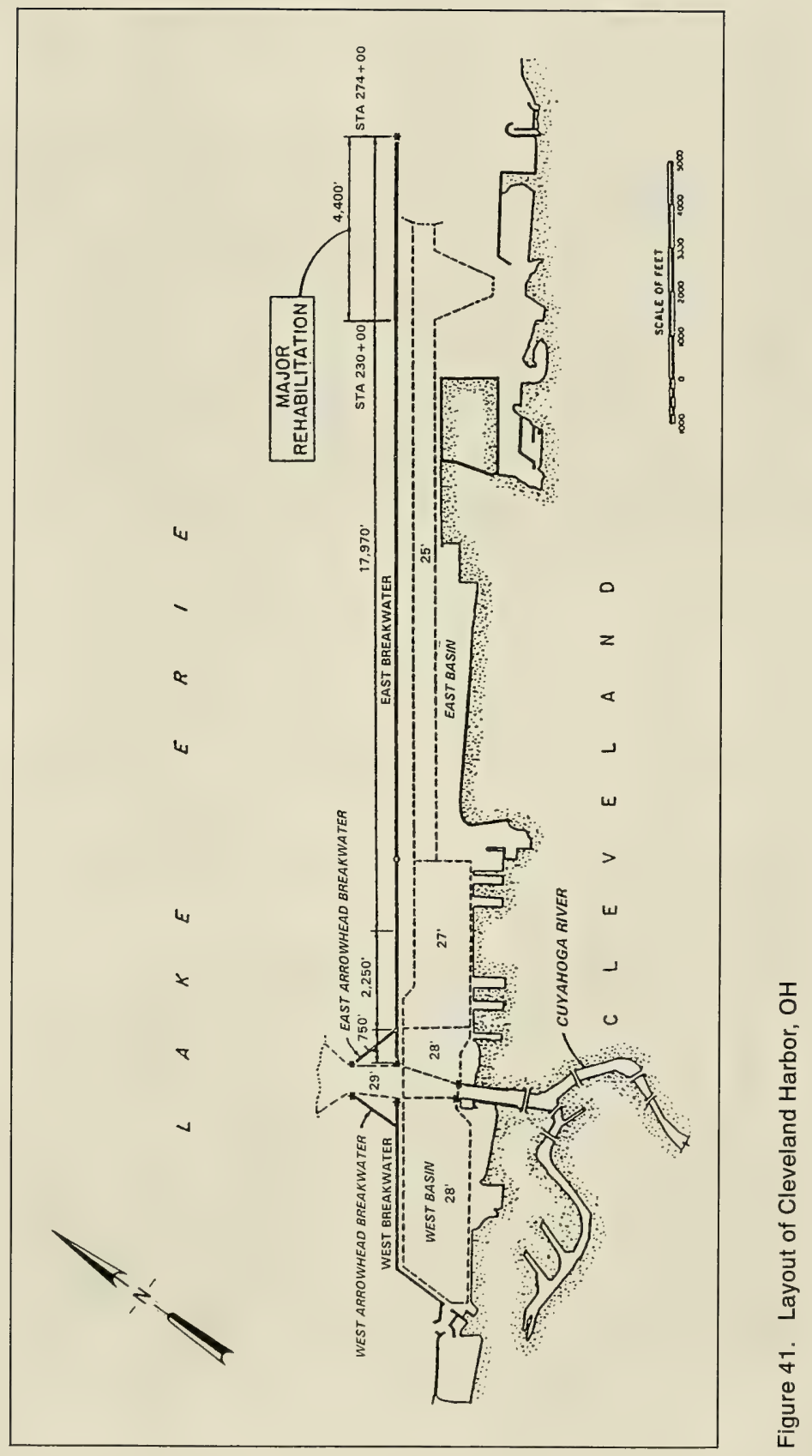


magnitude of armor unit breakage, which could compromise the integrity of the structure. It included the collection of aerial photography, wave and water level data, survey data to determine armor unit movement above the waterline, an inventory of broken dolos units, time-lapse photography, and underwater surveys using both side-scan sonar and diver inspections. As evidenced by significant movement and breakage during the monitoring study, the 1,814-kg (2-ton) dolosse appeared to be underdesigned. A total of 692 broken units were observed above the waterline at the conclusion of the study. Subsequent to the monitoring, in the spring of 1987 , it was noted that most of the dolosse around the head of the eastern end of the structure were missing. The damage was repaired in May 1987 with 3,628-kg (4-ton) dolos armor units as opposed to the 1,814-kg (2-ton) units previously used. Several 3,628-kg (4-ton) dolosse were also placed in low areas along the trunk to bring it back to the correct elevation. The east breakwater was monitored from July through November 1993 under the "Periodic Inspections" work unit of the MCNP program. Monitoring consisted of limited ground surveys, low-altitude aerial photography, photogrammetric analysis, and a broken armor unit survey (Bottin, Marcus, and Mohr 1995). Very accurate armor unit positions on the breakwater were obtained as well as detailed topography and point plot maps on the above-water portion of the structure. A total of 782 broken armor units indicated that the rate of breakage on the breakwater had drastically decreased compared with the period after initial construction.

The Cleveland Harbor east breakwater (Figures 42 and 43) was inspected on 7 October 1997. The inspection revealed that the structure has changed little since the 1993 survey. Comparison of armor unit positions

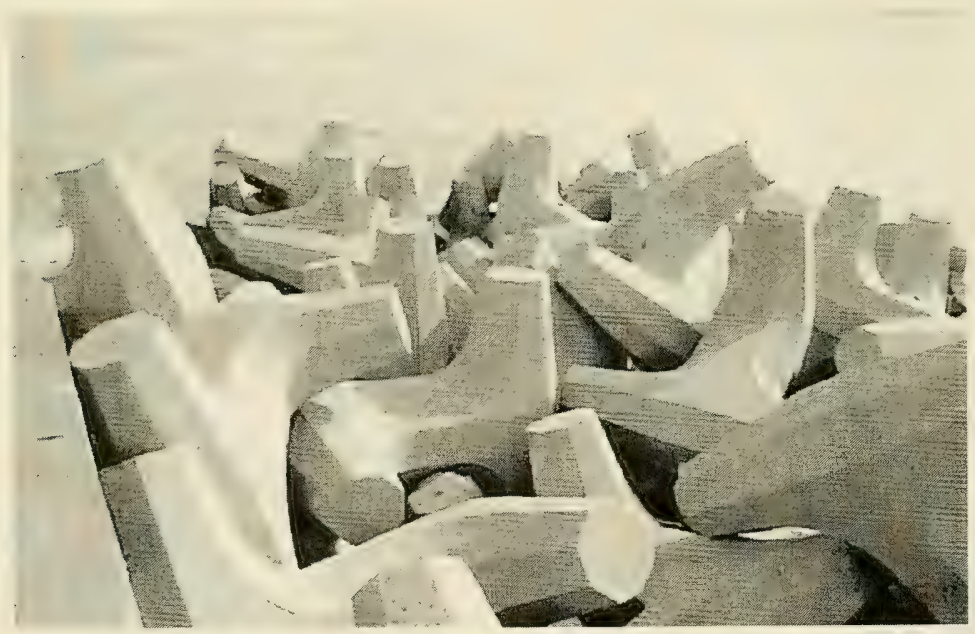

Figure 42. View of 3,628-kg (4-ton) dolosse at head of Cleveland Harbor east breakwater 


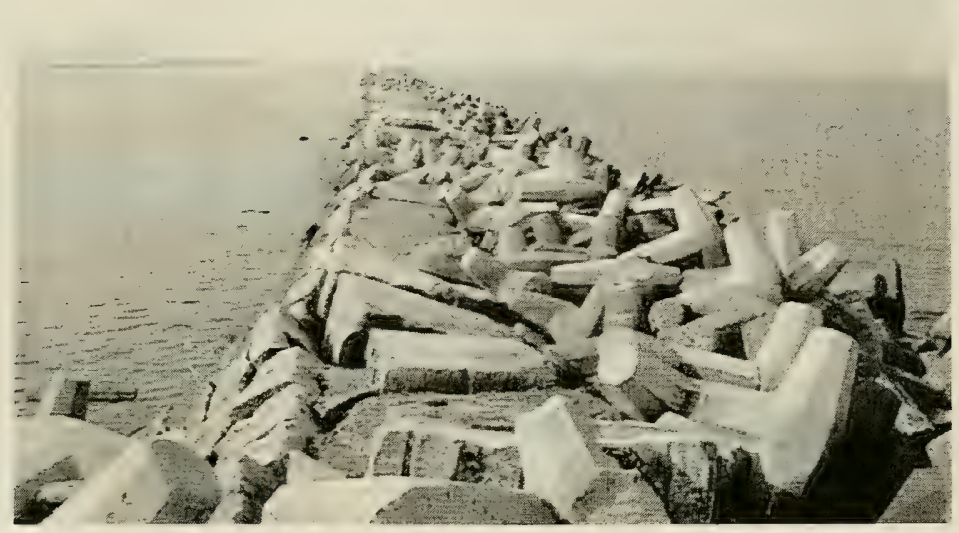

Figure 43. View of 1,814-kg (2-ton) dolosse along trunk of Cleveland Harbor east breakwater

with detailed, rectified aerial photography, in general, revealed that most of the armor units were in the same position as in 1993. Even fragments of broken dolosse were in the same positions based on the aerial photographs. Apparent armor unit movement was observed at only one location along the structure. At sta $262+55$ one dolos had moved downslope slightly and an adjacent dolos had flipped upslope. It was also noted that some new 3,628-kg (4-ton) dolosse had been placed between sta $253+50$ and $254+00$ since 1993 . The structure is in fair to good condition and appears to be functioning well.

\section{Cattaraugus Creek Harbor Breakwater, New York}

Cattaraugus Creek Harbor, New York, is located on Lake Erie approximately $38 \mathrm{~km}$ (24 miles) southwest of Buffalo, NY, and $87 \mathrm{~km}$ (54 miles) northeast of Erie, PA. The project consists of two breakwaters in Lake Erie at the mouth of the creek, a north breakwater $183 \mathrm{~m}$ long $(600 \mathrm{ft}$ long), and a south breakwater $564 \mathrm{~m}$ long (1,850 ft long); an entrance channel with el $-1.7 \mathrm{~m}(-5.5 \mathrm{ft}) \mathrm{lwd}$; and an interior channel extending upstream about $1,067 \mathrm{~m}(3,500 \mathrm{ft})$ with el $-1.1 \mathrm{~m}(-3.5 \mathrm{ft}) 1 \mathrm{wd}$. The breakwaters are of rubble-mound construction, and the south structure has a massive concrete cap, which provides a walkway for fishermen. Armor stone for the south breakwater ranges from $1,814 \mathrm{~kg}$ to $4,536 \mathrm{~kg}$ ( 2 to 5 tons) at the shore end to $5,443 \mathrm{~kg}$ to $11,793 \mathrm{~kg}$ ( 6 to 13 tons) at the 
head; and for the north breakwater from $1,814 \mathrm{~kg}$ to $4,536 \mathrm{~kg}$ ( 2 to 5 tons). Improvements at the site were completed in 1985. A layout of the structures is shown in Figure 44.

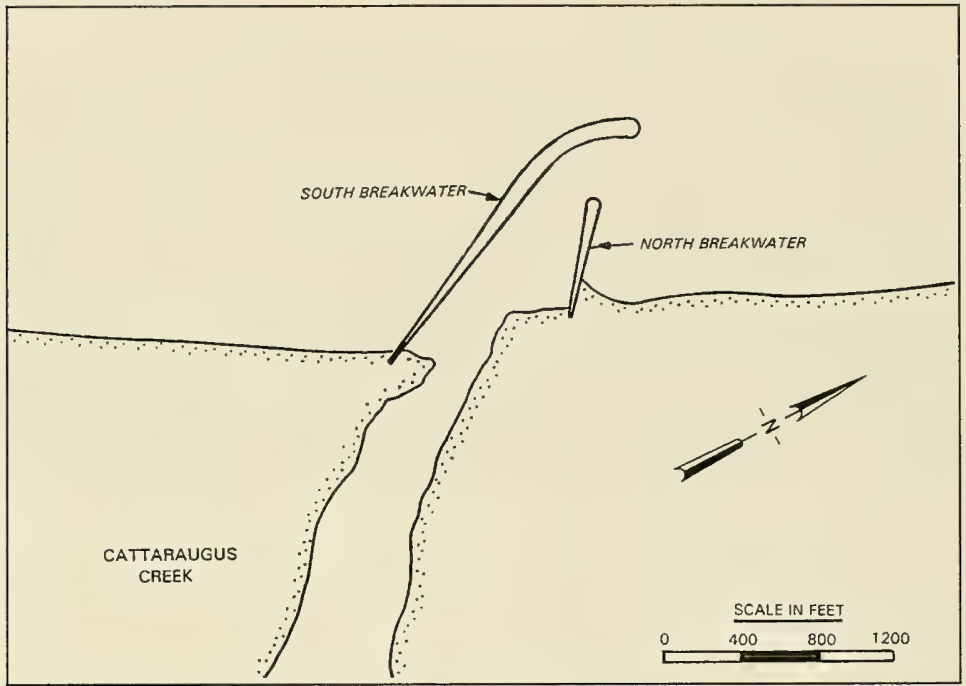

Figure 44. Layout of Cattaraugus Creek Harbor breakwaters, New York

The shore-connected breakwaters and channel improvements at Cattaraugus Creek Harbor were monitored between mid-1983 and 1985 under the MCNP program (Hemsley, Bottin, and Mohr 1991). Waves, structure stability, sediment transport, channel stability, and ice-jam problems due to the construction of the project were evaluated. At the conclusion of the monitoring it was noted that localized damage had occurred at the south breakwater head. Damage appeared to be due to stone cracking. The loss of shattered stone caused adjacent stone to collapse into voids, resulting in a steepening of the structure slope.

An inspection of the Cattaraugus Creek Harbor south breakwater (Figure 45) on 8 October 1997 revealed voids in the armor stone layer at two locations on the lake side of the breakwater along the curved portion (sta $15+00$ and sta $16+50$ ). The void at sta $16+50$ is shown in Figure 46 . An additional void was observed on the head of the structure (Figure 47), which resulted in a steep slope. During the inspection several broken stones were observed sporadically along the structures; however, overall the structure appears to be in good condition. The north breakwater was inaccessible and not inspected. It is protected by the curved south structure. 


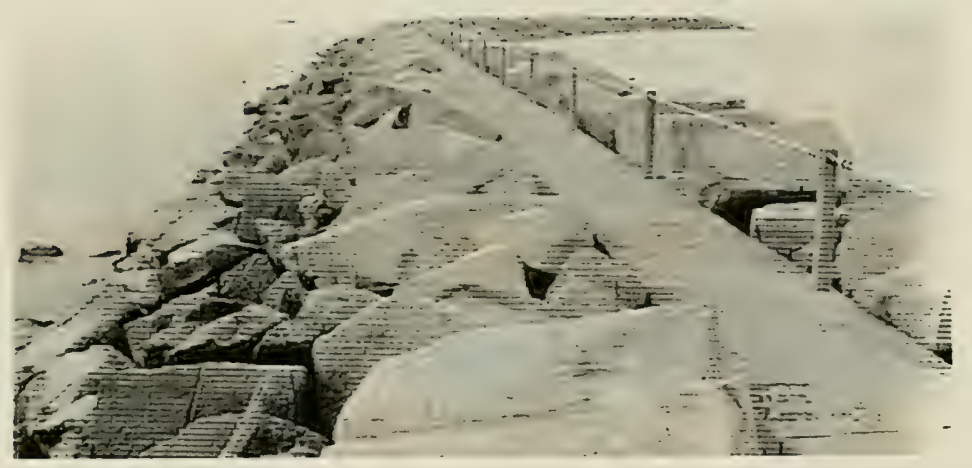

Figure 45. Cattaraugus Creek south breakwater looking lakeward

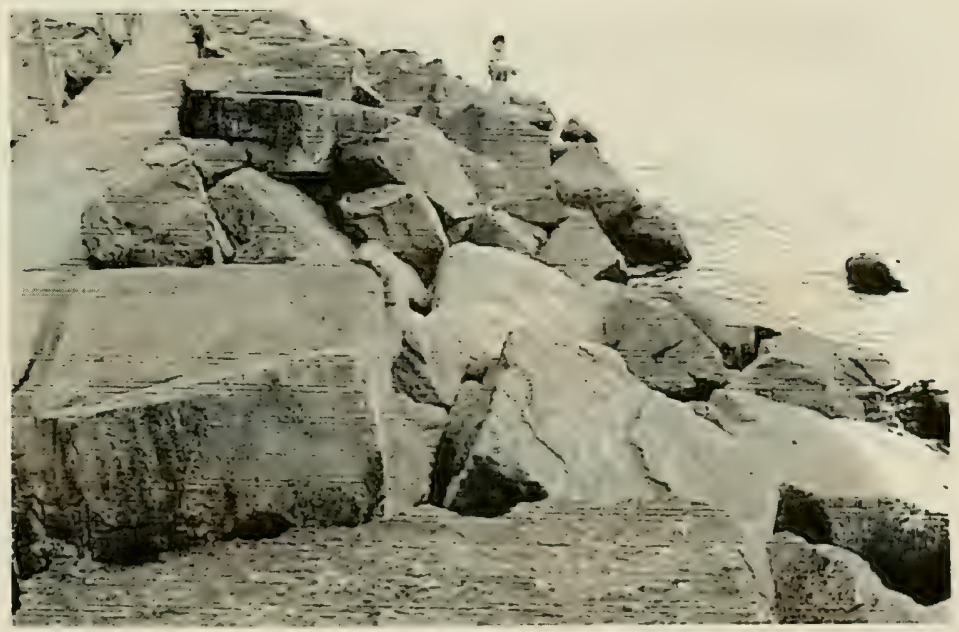

Figure 46. Void along trunk (sta $16+50$ ) of Cattaraugus Creek south breakwater 


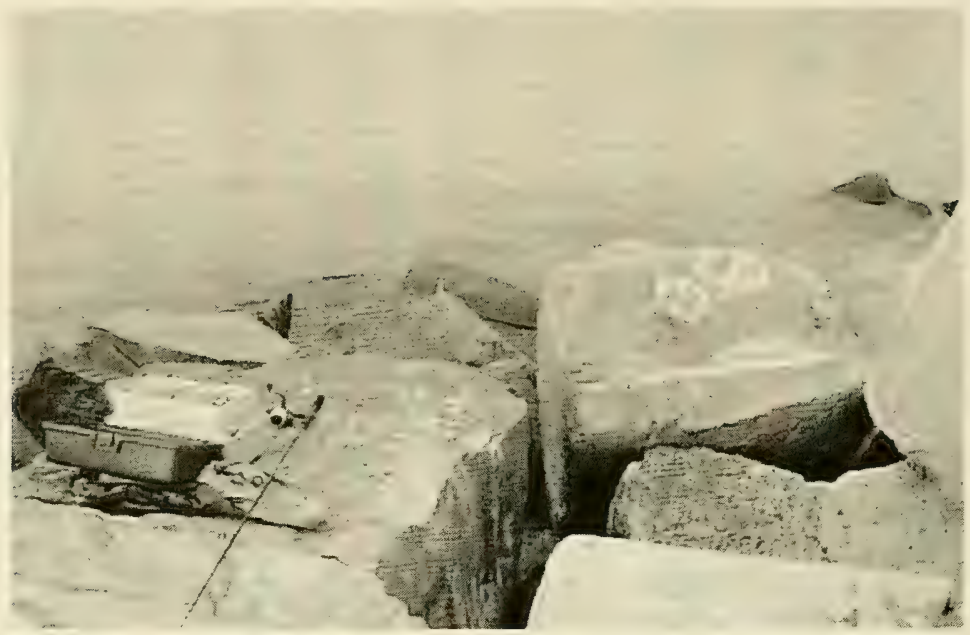

Figure 47. Void and steep slope at head of Cattaraugus Creek south breakwater

\section{Manasquan Inlet Jetties, New Jersey}

Manasquan Inlet is located on the Atlantic coast of New Jersey approximately $42 \mathrm{~km}$ (26 miles) south of Sandy Hook and $37 \mathrm{~km}$ (23 miles) north of Barnegat Inlet. The inlet provides the northernmost connection between the ocean and the New Jersey Intracoastal Waterway. Historical records indicate the inlet has migrated, and even closed on occasion, prior to jetty construction. Attempts to stabilize the inlet with timber jetties in 1883 and 1922 failed, leading to Congressional authorization of the present project in 1930. The project entailed the construction of two rubble jetties, with steel sheet-pile cores, spaced $122 \mathrm{~m} \mathrm{(400} \mathrm{ft)} \mathrm{apart} \mathrm{(Fig-}$ ure 48$)$. The north jetty was $375 \mathrm{~m}(1,230 \mathrm{ft})$ long, and the south jetty was $314 \mathrm{~m}(1,030 \mathrm{ft})$ long. Armor consisted of 1,814-kg (2-ton) capstone, and the crest height of the jetties was $+4.3 \mathrm{~m}(+14 \mathrm{ft})$ mean low water (mlw). A 4.3-m-deep (14-ft-deep) mlw navigation channel was dredged between the jetties. Through the 1970 's the jetties were repeatedly damaged by storms and structural settlement. Numerous repairs were attempted, using armor stone of up to $10,890 \mathrm{~kg}$ (12 tons), without success. The jetties were rehabilitated in 1982 using 14,515-kg (16-ton) reinforced dolos armor units. On the south jetty, dolosse were placed on the outer $122 \mathrm{~m}(400 \mathrm{ft})$ of the north, or channel, side of the structure, around the head, and along the outer $37 \mathrm{~m} \mathrm{(120} \mathrm{ft)} \mathrm{of} \mathrm{the} \mathrm{south} \mathrm{side} \mathrm{of} \mathrm{the} \mathrm{structure.}$ On the north jetty, dolosse were placed along the outer $76 \mathrm{~m}(250 \mathrm{ft})$ of the structure on its north side, around the head, and along the outer $28 \mathrm{~m}$ $(90 \mathrm{ft})$ on the channel side. Inshore of the dolos sections, the slopes were armored with a single layer of $10,890-\mathrm{kg}$ (12-ton) stones. 


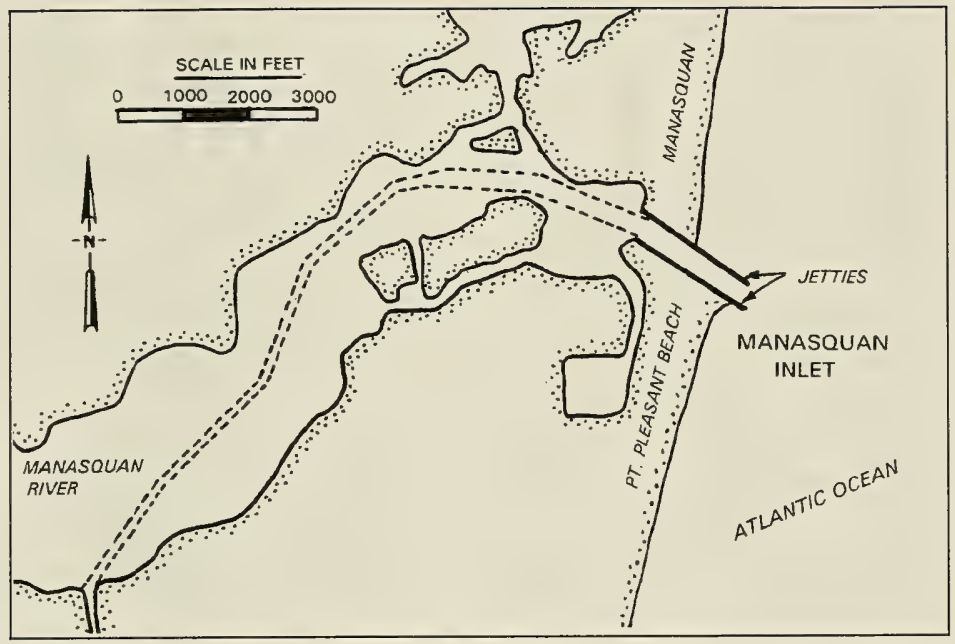

Figure 48. Layout of Manasquan Inlet jetties, New York

The Manasquan Inlet project was monitored during the period June 1982 to October 1984 under the MCNP program (Gebert and Hemsley 1991). Objectives of the study were to evaluate the performance of the dolos armor units in maintaining structural stability of the jetties, determine potential effects of the rehabilitated jetties on longshore sediment movement at the inlet, and determine the effectiveness of the rehabilitated jetties in maintaining a stable inlet cross section. Data collection included wave measurements, tidal elevation and current measurements, side-scan sonar surveys, hydrographic surveys, limited ground surveys, aerial photography, and photogrammetric analysis. The jetties were subsequently monitored under the "Periodic Inspections" work unit of the MCNP program from August through November 1994 (Bottin and Gebert 1995). Monitoring consisted of limited ground surveys, aerial photography, photogrammetric analysis, and a broken armor unit survey. Detailed photomaps of the above-water portion of the structures were obtained. The monitoring revealed void areas on both jetty heads. On the north jetty, the void area was on the south side of the head. The void area on the south jetty was at its tip, and core stone was exposed in this location. Emergency repair work, consisting of the placement of grout-filled bags, was completed subsequent to the survey on the south jetty as a temporary measure.

The Manasquan Inlet jetties were inspected on 10 June 1997. The 14,515-kg (16-ton) dolos armor units are shown in Figure 49. Visual comparisons of armor unit positions on the north jetty to 1994 photomaps revealed that several units had moved slightly. Horizontal movement appeared to range from 0.15 to $0.6 \mathrm{~m}(0.5$ to $2 \mathrm{ft})$. In addition, it appeared that the downslope portions of most of these units had slightly lost 


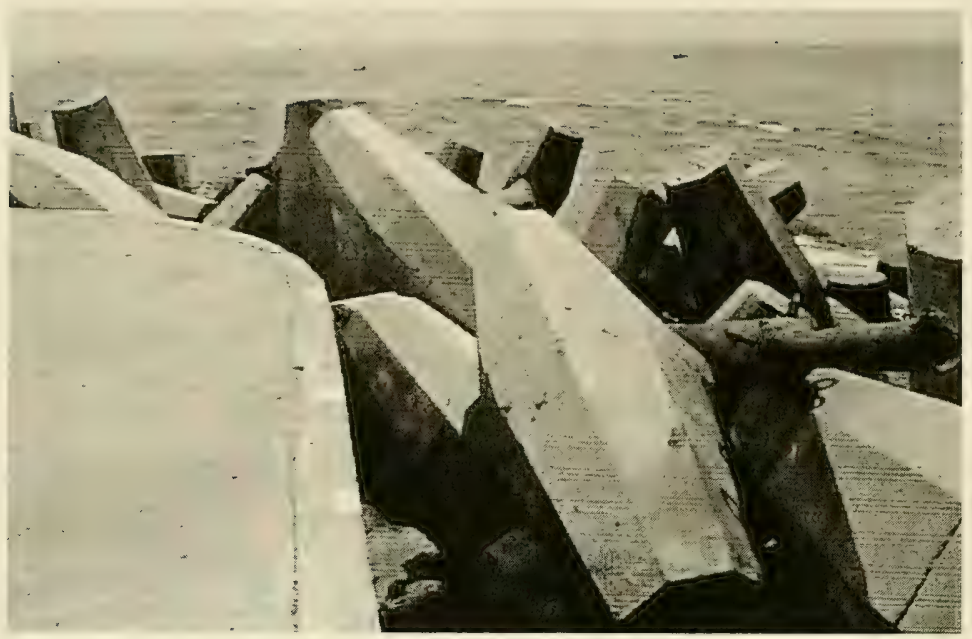

Figure 49. 14,515-kg (16-ton) dolos armor units on Manasquan Inlet jetties

elevation. Seven of these units were adjacent to the void area (Figure 50) on the south side of the jetty head, which had been identified in the 1994 survey. The void area also appeared slightly larger than in 1994. Two armor units on the north side of the structure and four on the seaward tip of

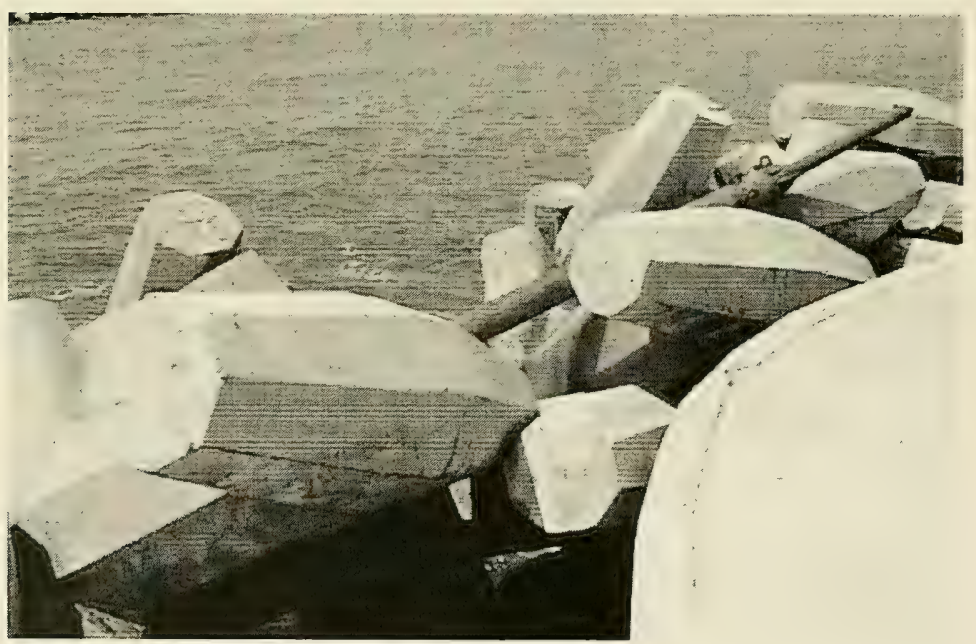

Figure 50. Void area on south side of Manasquan Inlet north jetty head 
the jetty also had moved downslope slightly. Most of these movements probably may be attributed to a major storm that occurred in 1995 . Inspection of the south jetty revealed that two armor units on the north side of the head had moved slightly shoreward. The area at the head of the south jetty, where the emergency repair work had been completed, appeared to be intact and performed well during the 1995 storm (Figure 51). The storm had washed the lighthouse structure onto the dolosse armor (Figure 52). No additional armor breakage was observed on either jetty during the inspection.

Subsequent to the 1997 inspection (in October 1997), void areas of both jetties were rehabilitated with 17,235-kg (19-ton) CORE-LOC armor units. Twenty-nine CORE-LOCs were placed on the north jetty and 16 on the south jetty interlocking with the existing dolosse. In addition, nine dolosse were repositioned to improve interlocking and seven broken units were removed. Other dolosse were repositioned slightly to provide space for the integration of the new CORE-LOCs into the overall protection plan.

\section{Ocean City Inlet South Jetty, Maryland}

Ocean City Inlet, Maryland, is located about $56 \mathrm{~km}$ (35 miles) south of the entrance to Delaware Bay and $170 \mathrm{~km}$ (105 miles) north of the Virginia Capes. The inlet was opened in August 1933 due to a severe hurricane. Congress subsequently authorized stabilization of the natural inlet.

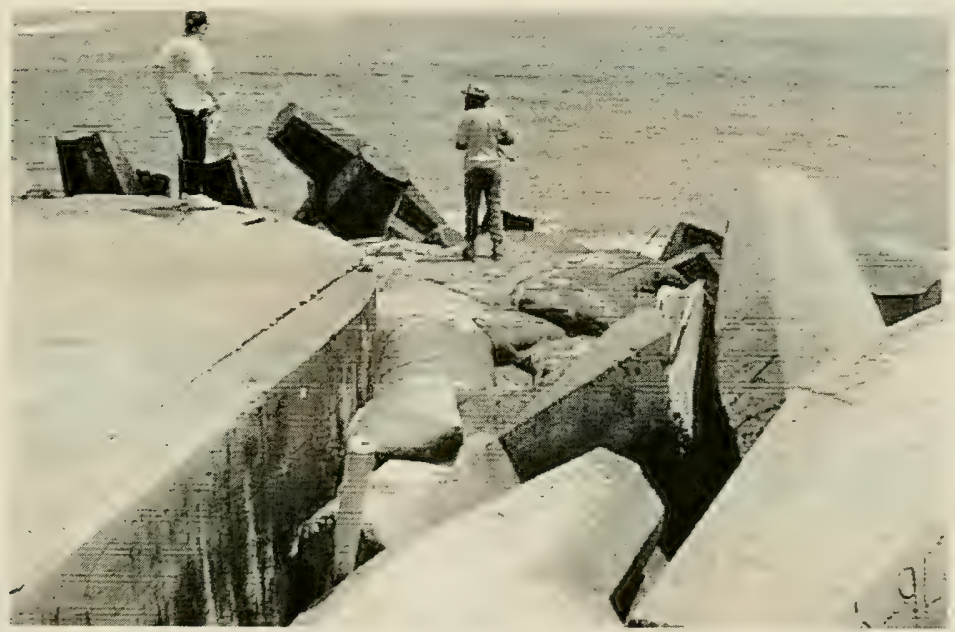

Figure 51. Emergency repair work (grout-filled bags) at head of Manasquan Inlet south jetty 


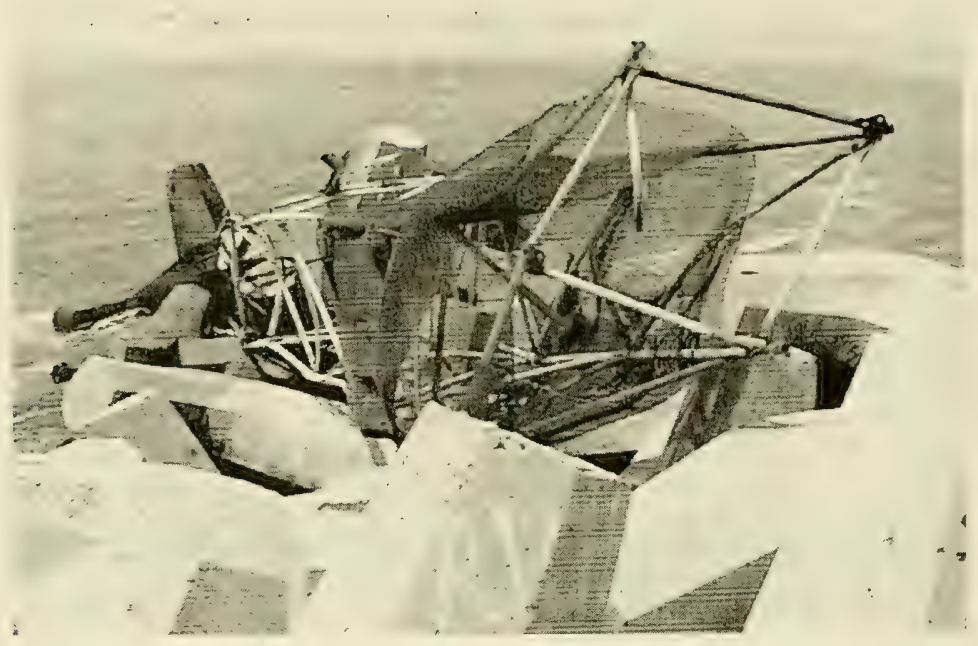

Figure 52. Lighthouse base washed into Manasquan Inlet south jetty as a result of 1995 storm

A north jetty (Figure 53) was constructed in 1934 to a length of about $335 \mathrm{~m}(1,100 \mathrm{ft})$ and an el of $+0.8 \mathrm{~m}(+2.7 \mathrm{ft}) \mathrm{mlw}$. Subsequent rehabilitations resulted in the structure being raised to an el of $+3.3 \mathrm{~m}(+10.7 \mathrm{ft})$ $\mathrm{mlw}$ for the shoreward $30 \mathrm{~m}(100 \mathrm{ft})$ and to an el of $+2.3 \mathrm{~m}(+7.7 \mathrm{ft}) \mathrm{mlw}$

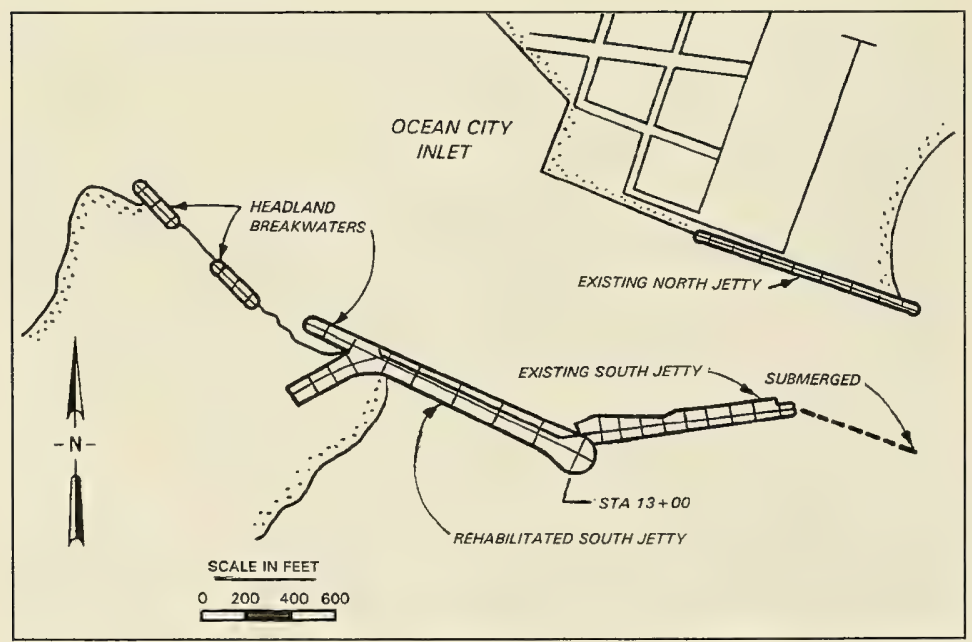

Figure 53. Layout of Ocean City Inlet structures, Maryland 
for the remainder of its length. The south jetty was originally constructed in 1935 with a length of about $725 \mathrm{~m}(2,380 \mathrm{ft})$. The shoreward section paralleled the north jetty for a distance, and then it angled toward the north jetty, reducing the inlet width. It then paralleled the north jetty again at its seaward end. The crest elevation of all but the seaward portion was $+1.4 \mathrm{~m}(+4.7 \mathrm{ft}) \mathrm{mlw}$. The elevation of the outer $110 \mathrm{~m}(360 \mathrm{ft})$ of the jetty decreased from $+1.4 \mathrm{~m}(+4.7 \mathrm{ft}) \mathrm{mlw}$ to $1.2 \mathrm{~m}(4 \mathrm{ft})$ above the existing bottom.

A new south jetty section was constructed in 1985. It was about $395 \mathrm{~m}$ $(1,300 \mathrm{ft})$ in length and offset $9.1 \mathrm{~m}(30 \mathrm{ft})$ southerly of the existing jetty center line. The existing jetty was left intact. The new section was constructed with core stone, intermediate stone, one layer of capstone, and precast concrete units along the center line (in the trunk) to form a core impermeable to sand transport. The elevation of the structure was increased to $+2.3 \mathrm{~m}(+7.5 \mathrm{ft}) \mathrm{mlw}$, and capstone ranged from 5,445 to $13,610 \mathrm{~kg}$ ( 6 to 15 tons). The impermeable core wall along the center line consisted of precast, steel-reinforced, concrete units with tongue-ingroove interlock joints to maintain alignment and impermeability. The units were $1.8 \mathrm{~m}(6 \mathrm{ft})$ wide by $0.6 \mathrm{~m}(2 \mathrm{ft})$ long by $1.8 \mathrm{~m}(6 \mathrm{ft})$ high.

In addition to the south jetty, three headland breakwaters were constructed to stabilize the shoreline adjacent to the shore end of the jetty.

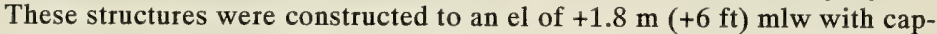
stones ranging from 2,720 to $4,535 \mathrm{~kg}$ ( 3 to 5 tons). One was $104 \mathrm{~m}$ $(340 \mathrm{ft})$ in length and tied into the south jetty, and the other two were each $61 \mathrm{~m}(200 \mathrm{ft})$ in length.

The rehabilitated south jetty at Ocean City Inlet was monitored during the period October 1986 through January 1989 (Bass et al. 1994) as part of the MCNP program. Activities included beach and offshore surveys, aerial and ground photography of the inlet and adjacent shorelines, inlet hydraulic surveys, nondirectional wave gauging, and side-scan sonar surveys of scour areas.

The rehabilitated south jetty and headland breakwaters at Ocean City Inlet were inspected on 11 June 1997. The rehabilitated south structure is shown in Figures 54 and 55, and the headland structures are shown in Figure 56. The inspection revealed these structures to be in excellent condition. No voids were noted, no armor stones were broken, and the cross sections of the structures appeared to be as built. It was noted that the seaward section of the old south jetty (that extending beyond sta $13+00$ ) was in disarray. Armor stones were scattered, the crest height was inconsistent, and no definite cross section was apparent (Figure 57). 


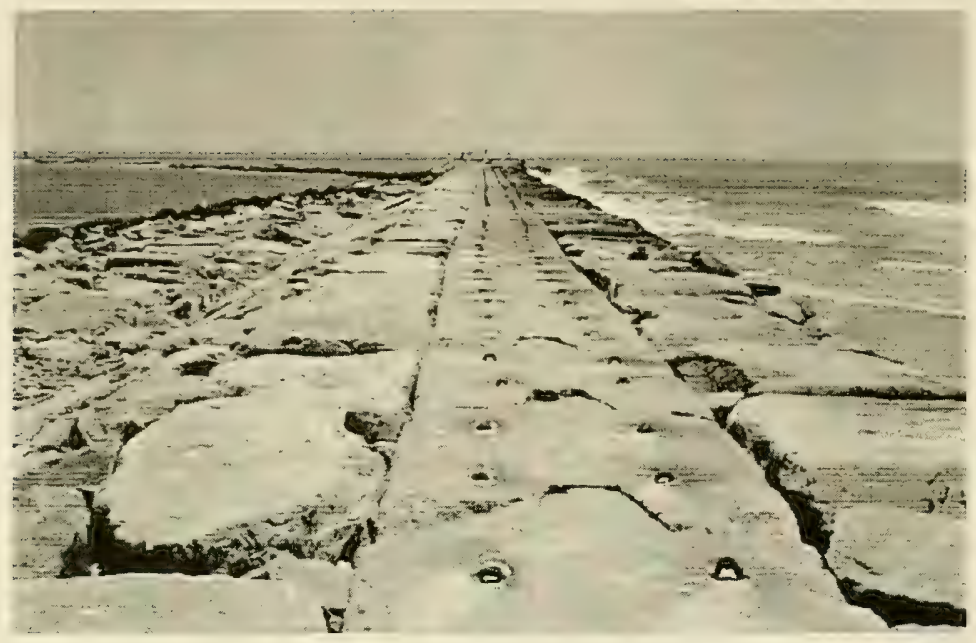

Figure 54. Rehabilitated south jetty trunk at Ocean City Inlet

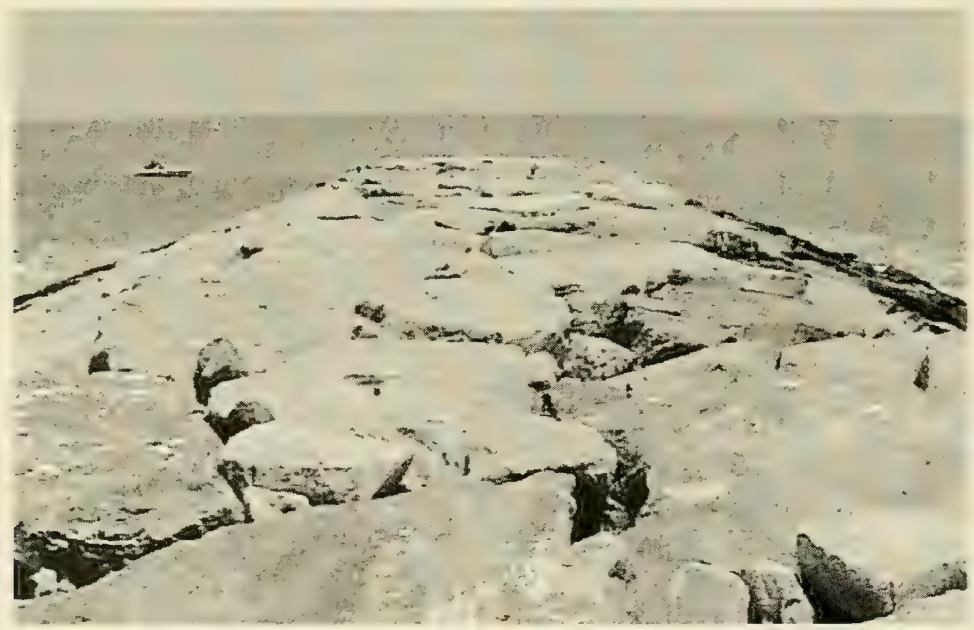

Figure 55. Head portion of south jetty rehabilitation at Ocean City Inlet 


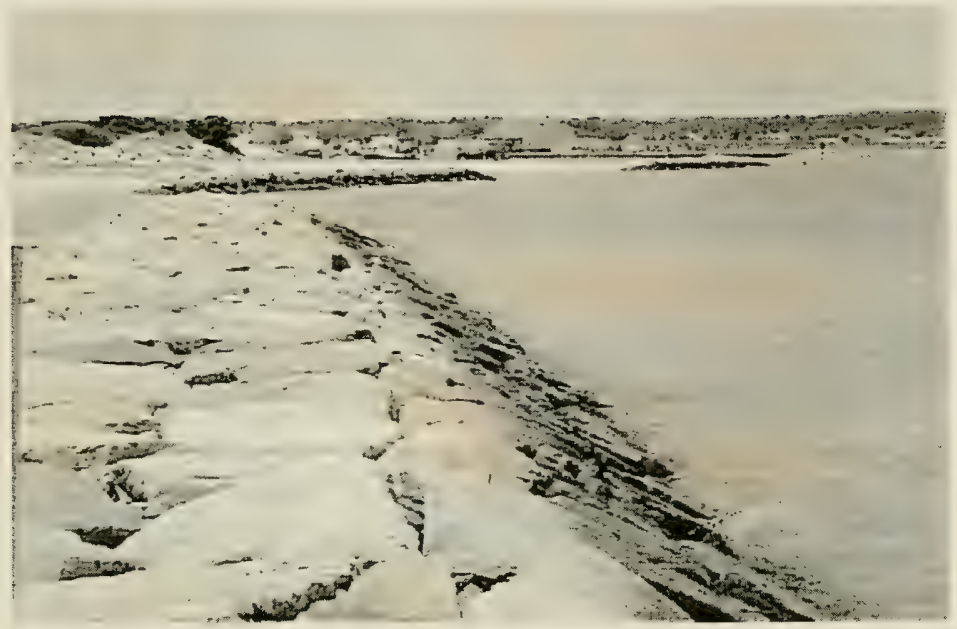

Figure 56. Headland breakwaters at Ocean City Inlet constructed to stabilize shoreline

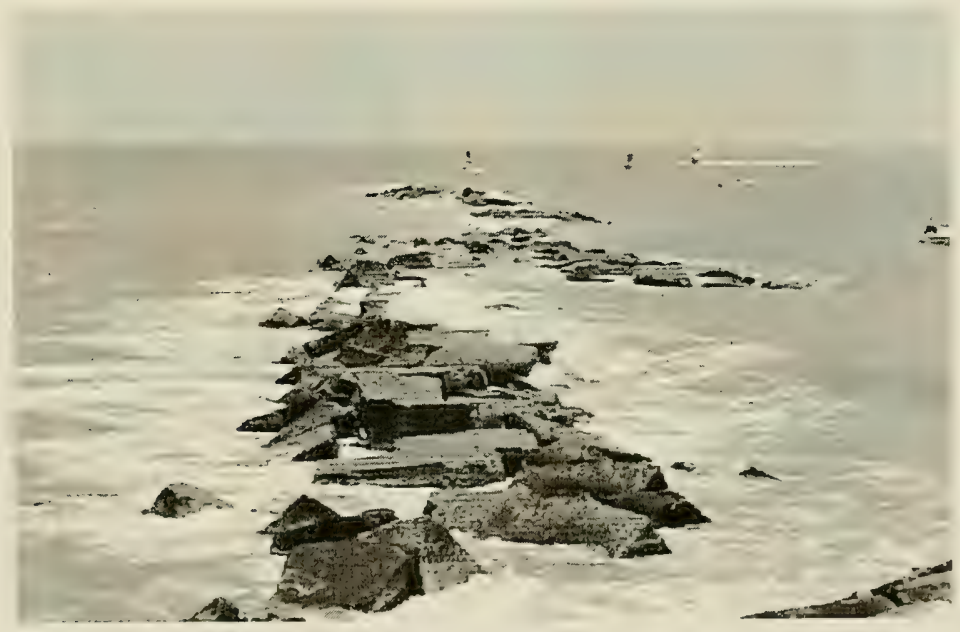

Figure 57. Seaward section of existing south jetty at Ocean City Inlet (beyond sta 13+00) 


\section{Summary and Recommendations}

Coastal structures previously monitored under the MCNP program at 14 sites were inspected from June 1997 through September 1998. These were expedient, low-cost assessments consisting of walking inspections and/or boat surveys. Changes in the structures since they were last surveyed were noted. Summaries of the results as well as recommendations are presented in the following subparagraphs:

a. Inspection of the Nawiliwili Harbor breakwater, Kauai, HI, indicated that there was very little change in armor unit positions compared with the previous survey of 1995 . Broken armor units were observed (as in 1995) as well as surface spalling of concrete for some of the armor units. The structure is not felt to be in danger of instability and overall is in good condition. It should be inspected periodically, and particularly subsequent to periods of high wave energy.

b. Inspection of the Kahului Harbor breakwaters, Maui, HI, indicated that most of the armor unit positions were similar to those of the previous survey of 1993. Two armor units had flipped and slid downslope on the east breakwater and two additional broken units (a total of 11 versus 9 in 1993) were noted on the sea side of the structure. A concentration of broken armor units was observed on the sea side of the head of the west breakwater; however, these were documented during the 1993 survey. No voids or breaches were noted in the breakwaters and the overall condition of the structures was considered good. They should be inspected periodically, particularly after significant storm events.

c. Inspection of the Laupahoehoe breakwater, Hawaii, HI, indicated that the armor units were in the same positions as documented in the previous survey of 1993. No broken armor units were observed, and the structure is in excellent condition. It should be inspected periodically.

d. Inspection of the Yaquina Bay north jetty, Oregon, indicated that the outer $50 \mathrm{~m}$ (165 ft) no longer existed above the waterline as compared with the previous survey of 1993. Remnants of some of the 
jetty could be seen seaward of the structure in wave troughs as they passed. Other observations revealed some low areas in the crest and some voids on the sea side of the jetty. Consideration should be given to designing a cap to stabilize the head of the jetty and prevent it from unraveling further. In addition, consideration should be given to placing armor stones in the voids of the structure during scheduled maintenance to prevent future major damage, and in areas along the structure crest to bring the jetty back to its design cross section. The structure should be checked after major storm events.

e. Inspection of the Siuslaw River jetties, Oregon, indicated that some damage had occurred since the previous monitoring in 1993. Voids at two locations on the channel side of the north jetty were observed as well as low areas in the center of the jetty crest. Damage on the head of the south jetty was observed as evidenced by a lack of stone above the water surface and a very steep slope. In addition, two void areas were noted on the shoreward side of the south jetty spur. Consideration should be given to placing armor stones in the voids and damaged areas identified on the jetties and jetty spur during scheduled maintenance to prevent further damage in the event of a major storm. Consideration should also be given to placing armor stones in areas along the structure's crest to bring it back to its design cross section. The structures should be inspected after major storm events.

f. Inspection of the Umpqua River training jetty, Oregon, indicated it was generally in very good condition. At the shoreward end of the structure it was noted that some stone from the jetty was scattered on the shore. Inspection of the south jetty indicated a breach at its head and a large void on the sea side of the structure just shoreward of the breach. The breach did not extend below the water surface. The trunk of the south jetty was in good condition. Consideration should be given to repairing the breach and void at the head of the south jetty with armor stones during scheduled maintenance to prevent further damage and potential failure of the structure in the event of a major storm. The breakwater system then should be inspected periodically especially after major storms.

g. Inspection of the Crescent City Harbor breakwater, California, indicated that most of the armor unit positions were similar to those of the previous survey of 1993 . Only a couple of units had slightly changed positions along the waterline on the sea side of the outer portion of the main stem. Broken armor units were observed, but validated as being broken during the 1993 survey. Overall the structure is in good condition. It should be periodically monitored, and particularly after major storm events.

$h$. Inspection of the Spud Point Marina breakwater, California, indicated no evidence of misalignment, movement, spalling, or subsidence of the structure. Hairline cracks across the breakwater cap 
noted in the previous survey of 1989 had not widened; however, additional cracks were observed along the vertical sides of the concrete cap. These cracks do not appear to threaten the integrity of the structure. The breakwater is in very good to excellent condition. Future operations and maintenance inspections should reexamine the cracks to determine if they are growing wider and progressing through the breakwater cap.

i. Inspection of the Fisherman's Wharf Harbor breakwaters, California, indicated no evidence of deterioration or settlement of the structures. Numerous areas along the concrete piles between the main breakwater cap and the waterline, however, were spalled. These areas are not threatening the structural integrity of the function of the structure, and the breakwaters are in very good to excellent condition. Consideration should be given to grout-patching the spalled areas during routine maintenance operations to prevent rusting/ corrosion of the reinforcing steel in the exposed areas.

j. Inspection of the Burns Harbor breakwater, Indiana, indicated that the structure appeared to have settled in several areas compared to the topography of the previous survey of 1995 . The inspection also indicated additional voids in the structure. In general, it appeared that continued deterioration had occurred since the previous survey. Construction of a submerged reef breakwater lakeward of the structure was in progress during the inspection and scheduled to be completed during the fall of 1998. The reef structure was designed to reduce wave heights at the breakwater during storms and prevent subsequent damage. The Burns Harbor breakwater should be formally monitored through photogrammetry to quantify changes since the survey of 1995 and to develop base conditions upon which to evaluate the performance of the reef breakwater.

$k$. Inspection of the Cleveland Harbor east breakwater, Ohio, indicated that the structure had changed little since the previous survey of 1993. Comparison of armor unit positions revealed that most were in the same locations. Even fragments of broken units were in the same positions. Apparent armor unit movement was observed at only one location on the breakwater. Numerous broken units were observed but verified as being broken during the 1993 survey. The structure is in fair to good condition and appears to be functioning well. It should be inspected periodically, and particularly after storm events.

l. Inspection of the Cattaraugus Creek Harbor south breakwater, New York, indicated voids in the armor stone layer at two locations on the lake side along the curved portion of the south breakwater. Another void was noted at the head of the structure, which resulted in a steep slope. Broken armor stones were observed sporadically along the structure; however, overall the structure appears to be in good condition. Consideration should be given to placing armor stones in 
the voids identified during scheduled maintenance to prevent additional damage during storm wave events.

$m$. Inspection of the Manasquan Inlet jetties, New Jersey, indicated that several armor units on the north jetty had changed position slightly since the previous survey of 1994. It also appeared that the down-slope portions of these units had lost elevation. Most of these armor units were adjacent to a void area on the south side of the jetty head, which had been identified during the 1994 survey. The void area also appeared slightly larger than in 1994. On the south jetty, some units on the north side of the head had moved slightly since the 1994 inspection. Emergency repair work had been completed in a void on the south jetty head that had been identified during the survey of 1994. Subsequent to the inspection, both jetty void areas were repaired with CORE-LOCs along with some repositioning of the existing dolosse armor units. The Manasquan Inlet jetties should be formally monitored through photogrammetry to quantify changes since the survey of 1994, and to develop base conditions upon which to evaluate the performance of the new CORE-LOCs.

n. Inspection of the Ocean City Inlet south jetty, Maryland, indicated the structure to be in excellent condition. No voids were noted, no armor stones were broken, and the jetty cross section appeared to be as built. The structure should be inspected periodically, and particularly after a major storm event. 


\section{References}

Bass, G. P., Fulford, E. T., Underwood, S. G., and Parson, L. E. 1994. "Rehabilitation of the South Jetty, Ocean City, Maryland," Technical Report CERC-94-6, U.S. Army Engineer Waterways Experiment Station, Vicksburg, MS.

Bottin, R. R., Jr., and Boc, S. J. 1996. "Periodic inspection of Nawiliwili Harbor breakwater, Kauai, Hawaii; Report 1, Base conditions," Technical Report CERC-96-5, U.S. Army Engineer Waterways Experiment Station, Vicksburg, MS.

Bottin, R. R., Jr., and Gebert, J. A. 1995. "Periodic inspection of jetties at Manasquan Inlet, New Jersey; Report 1, Armor unit monitoring for period 1984-1994," Technical Report CERC-95-19, U.S. Army Engineer Waterways Experiment Station, Vicksburg, MS.

Bottin, R. R., Jr., and Matthews, E. W. 1996. "Periodic inspection of Burns Harbor north breakwater, Indiana; Report 1, Base conditions," Technical Report CERC-96-8, U.S. Army Engineer Waterways Experiment Station, Vicksburg, MS.

Bottin, R. R., Jr., Marcus, D. W., and Mohr, M. C. 1995. "Periodic inspection of Cleveland Harbor east breakwater, Ohio; Report 1, Base conditions," Technical Report CERC-95-3, U.S. Army Engineer Waterways Experiment Station, Vicksburg, MS.

Gebert, J. A., and Hemsley, J. M. 1991. "Monitoring of jetty rehabilitation at Manasquan Inlet, New Jersey," Miscellaneous Paper CERC-918, U.S. Army Engineer Waterways Experiment Station, Vicksburg, MS.

Hemsley, J. M., Bottin, R. R., Jr., and Mohr, M. C. 1991. "Monitoring of completed breakwaters at Cattaraugus Creek Harbor, New York," Miscellaneous Paper CERC-91-10, U.S. Army Engineer Waterways Experiment Station, Vicksburg, MS.

Herndon, H. D., Andrew, M. E., Hemsley, J. M., and Bottin, R. R., Jr. 1992. "Monitoring jetty improvements at Umpqua River, Oregon," Miscellaneous Paper CERC-92-1, U.S. Army Engineer Waterways Experiment Station, Vicksburg, MS. 
Hughes, S. A., Prickett, T. L., Tubman, M. W., and Corson, W. D. 1995. "Monitoring of the Yaquina Bay entrance north jetty at Newport, Oregon; Summary and results," Technical Report CERC-95- 9, U.S. Army Engineer Waterways Experiment Station, Vicksburg, MS.

Lott, J. W. 1991. "Spud Point Marina breakwater, Bodega Bay, Sonoma County, California," Miscellaneous Paper CERC-91-5, U.S. Army Engineer Waterways Experiment Station, Vicksburg, MS.

Lott, J. W. 1994. "Fisherman's Wharf breakwater monitoring study, San Francisco, California," Miscellaneous Paper CERC-94-8, U.S. Army Engineer Waterways Experiment Station, Vicksburg, MS.

Markle, D. G., and Boc, S. J. 1994. "Periodic inspections of Kahului and Laupahoehoe breakwaters, Hawaii; Report 1, Base conditions," Technical Report CERC-94-12, U.S. Army Engineer Waterways Experiment Station, Vicksburg, MS.

Markle, D. G., Melby, J. A., and Kendall, T. R. 1995. "Periodic inspections of dolosse on Crescent City breakwater, Crescent City, California; Report 1, Monitoring data for period 1989-1993," Technical Report CERC-95-5, U.S. Army Engineer Waterways Experiment Station, Vicksburg, MS.

McGehee, D., Moritz, H., Prickett, T. L., and Shirley, J. 1997. "Burns Harbor, Indiana, monitoring study; Volume 1: Overview of approach and results," Technical Report CHL-97-5, U.S. Army Engineer Waterways Experiment Station, Vicksburg, MS.

Pollock, C. E., McGehee, D., Neihaus, R. W., Jr., Chesser, S. A., and Livingston, C. 1995. "Effectiveness of spur jetties at Siuslaw River, Oregon; Report 1, Prototype monitoring study," Technical Report CERC-95-14, U.S. Army Engineer Waterways Experiment Station, Vicksburg, MS.

Pope, J., Bottin, R. R., Jr., and Rowen, D. 1993. "Monitoring of east breakwater rehabilitation at Cleveland Harbor, Ohio," Miscellaneous Paper CERC-93-5, U.S. Army Engineer Waterways Experiment Station, Vicksburg, MS. 

Public reporting burden for this collection of information is estimated to average 1 hour per response, including the time for reviewing instructions, searching existing data sources, gathering and maintaining the data needed, and completing and reviewing the collection of information. Send comments regarding this burden estimate or any other aspect of this collection of information, including suggestions for reducing this burden, to Washington Headquarters Services, Directorate for Information Operations and Reports, 1215 Jefferson Davis Highway, Suite 1204, Arlington, VA 22202-4302, and to the Office of Management and Budget, Paperwork Reduction Project (0704-0188), Washington, DC 20503.

1. AGENCY USE ONLY (Leave blank)

\section{REPORT DATE}

March 1999

\section{REPORT TYPE AND DATES COVERED} Final report

\section{TITLF AND SUBTITLE}

Inspections of Previously Monitored Coastal Structures

5. FUNDING NUMBERS

WU $11 \mathrm{M}-7$

\section{AUTHOR(S)}

Robert R. Bottin, Jr., Larry R. Tolliver

7. PERFORMING ORGANIZATION NAME(S) AND ADDRESS(ES)

U.S. Army Engineer Waterways Experiment Station

3909 Halls Ferry Road, Vicksburg, MS 39180-6199

\section{SPONSORING/MONITORING AGENCY NAME(S) AND ADDRESS(ES)}

\section{U.S. Army Corps of Engineers}

Washington, DC 20314-1000

8. PERFORMING ORGANIZATION REPORT NUMBER

Technical Report CHL-99-3

10. SPONSORING/MONITORING AGENCY REPORT NUMBER

11. SUPPLEMENTARY NOTES

Available from National Technical Information Service, 5285 Port Royal Road, Springfield, VA 22161.

12a. DISTRIBUTION/AVAILABILITY STATEMENT

Approved for public release; distribution is unlimited. 12b. DISTRIBUTION CODE

\section{ABSTRACT (Maximum 200 words)}

This report presents results of inspections of coastal sructures monitored previously under the Monitoring Completed Navigation Projects (MCNP) Program. Expedient, low-cost inspections consisting of walking inspections and/or boat surveys were performed at 14 sites. Positions of breakwater and jetty armor units were compared with their positions in previous aerial photography and photogrammetric surveys. Settlement of portions of the structures as well as voids in their armor also were noted, and photographs of the structures were obtained. Summaries of the inspection results as well as recommendations are presented in this report. The work was conducted under the "Periodic Inspections" work unit of the MCNP program.

14. SUBJECT TERMS

Armor units

Breakwaters

Coastal structure inspections
CORE-LOCs

Dolosse

Jetties
15. NUMBER OF PAGES

60

16. PRICE CODE
17. SECURITY CLASSIFICATION OF REPORT

UNCLASSIFIED
18. SECURITY CLASSIFICATION OF THIS PAGE

UNCLASSIFIED
19. SECURITY CLASSIFICATION OF ABSTRACT 

Destroy this report when no longer needed. Do not return it to the originator. 

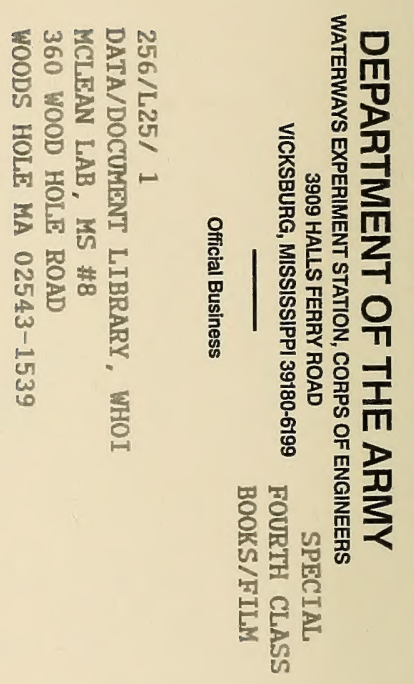